\title{
The deformation of the Egersund-Ogna anorthosite massif, south Norway: finite-element modelling of diapirism
}

\author{
J.D. Barnichon ${ }^{\text {a }}$, H. Havenith ${ }^{\text {b }}$, B. Hoffer ${ }^{\text {b }}$, R. Charlier ${ }^{\text {a }}$, D. Jongmans ${ }^{\text {b }}$, J.C. Duchesne ${ }^{\text {c,* }}$ \\ ${ }^{a}$ Département MSM, Université de Liège, 6 Quai Banning, B-4000 Liège, Belgium \\ ${ }^{b}$ Laboratoire de Géologie de l'Ingénieur, LGIH, Université de Liège, Bat. B19, B-4000 Sart Tilman, Belgium \\ ${ }^{c}$ Lab. Ass. Géologie, Pétrologie et Géochimie, Université de Liège, Bat. B20, B-4000 Sart Tilman, Belgium
}

Accepted 30 October 1998

\begin{abstract}
This paper aims at testing the mechanical relevance of the petrological model of anorthosite massif diapiric emplacement. The Egersund-Ogna massif (S. Norway) is of particular interest because recent petrological and geochronological data constrain the initial geometry, emplacement conditions and timing (about $2 \mathrm{~m} . \mathrm{y}$.). The formation of this anorthosite massif is in agreement with the classical petrological model, in which accumulation of plagioclase takes place in a deep-seated magma chamber at the crust-mantle limit, from which masses of plagioclase separate and rise through the lower crust up to the final level of emplacement at mid-crustal depths. The Egersund-Ogna massif also displays a foliated inner margin, in which strain ellipsoids have been reconstructed by investigating at 51 sites the deformation of megacrysts of high-alumina orthopyroxene. Based on these petrological data, a model made up of one rigid layer (upper granitic crust) and three viscous layers (lower part of the granitic crust, noritic lower crust and anorthosite) has been built up. The upper crust behaviour is represented by an elastoplastic law and the viscous layers obey elastic-viscoplastic laws with Newtonian viscosity. An inverse density gradient is considered between the lower crust $(d=3.00)$ and the anorthosite $(d=2.75)$, the loading consisting only in gravity. The modelling is carried out under axisymmetrical conditions, using the LAGAMINE finite-element code coupled with an automatic re-meshing algorithm designed to deal with large strains in complex structures. The results show that, from a mechanical point of view, the diapirism model is a robust and consistent assumption for the emplacement of anorthosites, because realistic diapir and rim-syncline shapes are obtained. Moreover, the numerically obtained emplacement time (about 2.5 m.y.) is in agreement with the available geochronological data, and the computed strain field is coherent with field measurements, especially regarding the circumferential extension, which becomes the largest extension strain component in the expansion phase. (c) 1999 Elsevier Science B.V. All rights reserved.
\end{abstract}

Keywords: anorthosite; diapir; finite-element modelling; Rogaland

\section{Introduction}

Diapirism results from the buoyant upwelling of a light viscous liquid when overlain by a heavier one.

\footnotetext{
* Corresponding author. Tel.: +32 4366 2255; Fax: +32 4366
} 2921; E-mail: jc.duchesne@ulg.ac.be
Such state is metastable, i.e. every perturbation of the system will lead to overturning the two liquid layers in order to reach the stable balanced state where the lighter liquid floats above the heavier one. The initial stage of this instability is described analytically by the Rayleigh-Taylor instability, observed both in plutonic and sedimentary environments, from 
crustal to metre scale (Rönnlund, 1989). Numerous examples of salt diapirism have been described (e.g. Jackson and Seni, 1983).

Pluton emplacement through diapirism has been the object of many petrological and structural studies. Since the pioneering field work of Pitcher and Berger (1972) and the experiments of Ramberg (1967), most studies have been essentially devoted to granites for which the concept of diapirs has been strongly debated (e.g. England, 1990; Paterson and Fowler, 1993; Vernon and Paterson, 1993; Vigneresse, 1995; Paterson and Vernon, 1996). It is beyond the scope of this article to discuss the different arguments about this controversial subject and we will only briefly present some main ideas. Following Brun et al. (1981) and England (1990), the main diagnostic criteria and structural features for the recognition of diapiric bodies are: (1) sub-circular shaped bodies of low density surrounded by denser rocks; (2) parallel foliations within the diapir and the host rocks; (3) increase of the strain intensity towards the margin of the diapir with a horizontal extension in the upper part of the diapiric structure; (4) important deformation in the country rocks; (5) development of a rim synform; (6) steeply plunging lineations and shear components. However, other processes like stoping, fracture-controlled emplacement, zone melting or ballooning can also be involved in the emplacement and deformation of plutons (Paterson et al., 1991). Many of the expected features of diapirs can therefore result from some or a combination of these mechanisms, and typical characteristics of ascent mechanism can be obliterated during emplacement or by younger tectonic processes. These are the reasons why direct evidence of diapirism is generally difficult to find out in plutons.

Diapirism has long been invoked for the emplacement of massif-type anorthosites. Martignole and Schrijver (1970) first attempted to interpret deformation structures in the Morin anorthosite in terms of syn-emplacement deformation due to buoyancy of anorthosite. The concept was further developed by Duchesne (1984), Longhi and Ashwal (1985) and Wiebe (1992) to become a basic component of the petrological model of anorthosite formation (Ashwal, 1993). Anorthosite plutons in classical areas of study such as the Adirondacks Mts or Morin massif (Québec) have been reworked by post-emplacement deformation and metamorphism (see e.g. Wiebe, 1992). Moreover, some of the features initially invoked in the Morin massif in favour of diapirism have now been reinterpreted by Martignole (1996) as resulting from tectonic transport along a shear zone. On the other hand, accurate $\mathrm{U}-\mathrm{Pb}$ dating of the Rogaland anorthosite plutonism (southern Norway) (Schärer et al., 1996) has shown that these anorthosites were emplaced later than the last regional deformation and, having thus escaped postemplacement deformation, are excellent examples of pristine anorthosites.

We recall here the petrological arguments in favour of diapirism of the Egersund-Ogna massif (EGOG), provide some data on the strain distribution in the inner margin of the intrusion, and present a finite-element (FE) simulation of the diapiric emplacement, in which geochronological and petrological data are used to define a reasonable geometry and rheology of the model. The main objective of this paper is to test the consistency of the petrological model by numerical modelling. A Lagrangian FE code coupled with an automatic re-meshing algorithm and artificial passive markers is used for the modelling.

\section{The EGOG massive anorthosite}

\subsection{Geological setting}

The Rogaland anorthositic province of southern Norway (Fig. 1A) encompasses three large

Fig. 1. (A) Geological map of the Rogaland anorthosite complex, southern Norway (after Michot and Michot, 1969; Wilson et al., 1996). Abbreviations: $A p=$ Apophysis, $\AA S=\AA ̊$ Ana-Sira anorthosite massif, $B K S K=$ Bjerkreim-Sokndal layered intrusion, $E G O G=$ Egersund-Ogna anorthosite massif, $E R=$ Eia-Rekefjord jotunitic intrusion, $G=$ Garsaknat leuconoritic body, $H=$ Hidra leuconoritic body, $H H=$ Håland-Helleren anorthosite massif. (B) Geological map of the Egersund-Ogna anorthosite massif (after Michot and Michot, 1969; Maquil and Duchesne, 1984; Duchesne and Maquil, 1987). Abbreviations: BKSK = Bjerkreim-Sokndal layered intrusion, $H H=$ Håland-Helleren anorthosite massif. Legend: $l=$ anorthosite; $2=$ anorthosite rich in HAOM; $3=$ leuconorite; $4=$ foliated anorthosite and leuconorite; $5=$ migmatitic gneiss. 


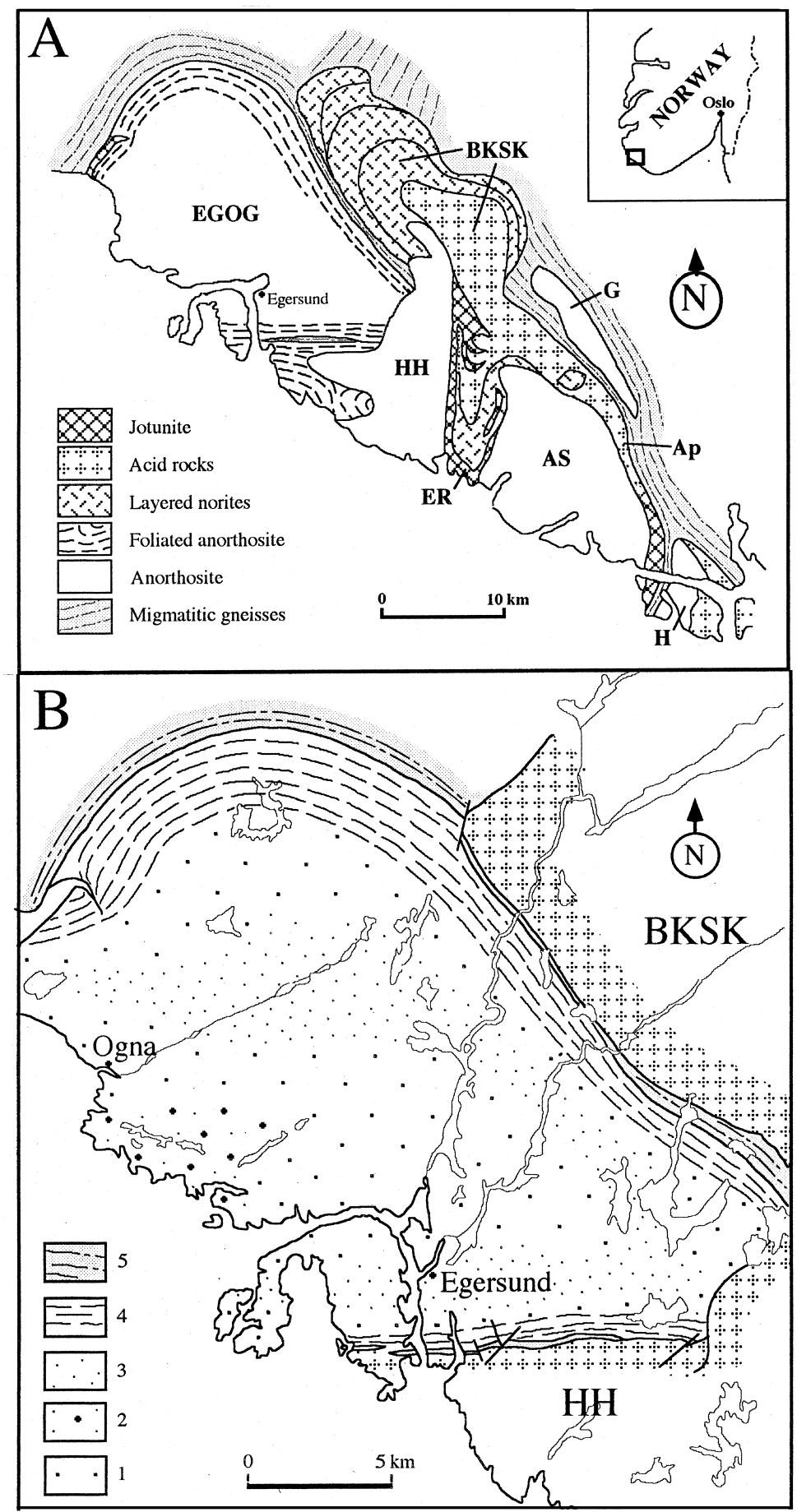



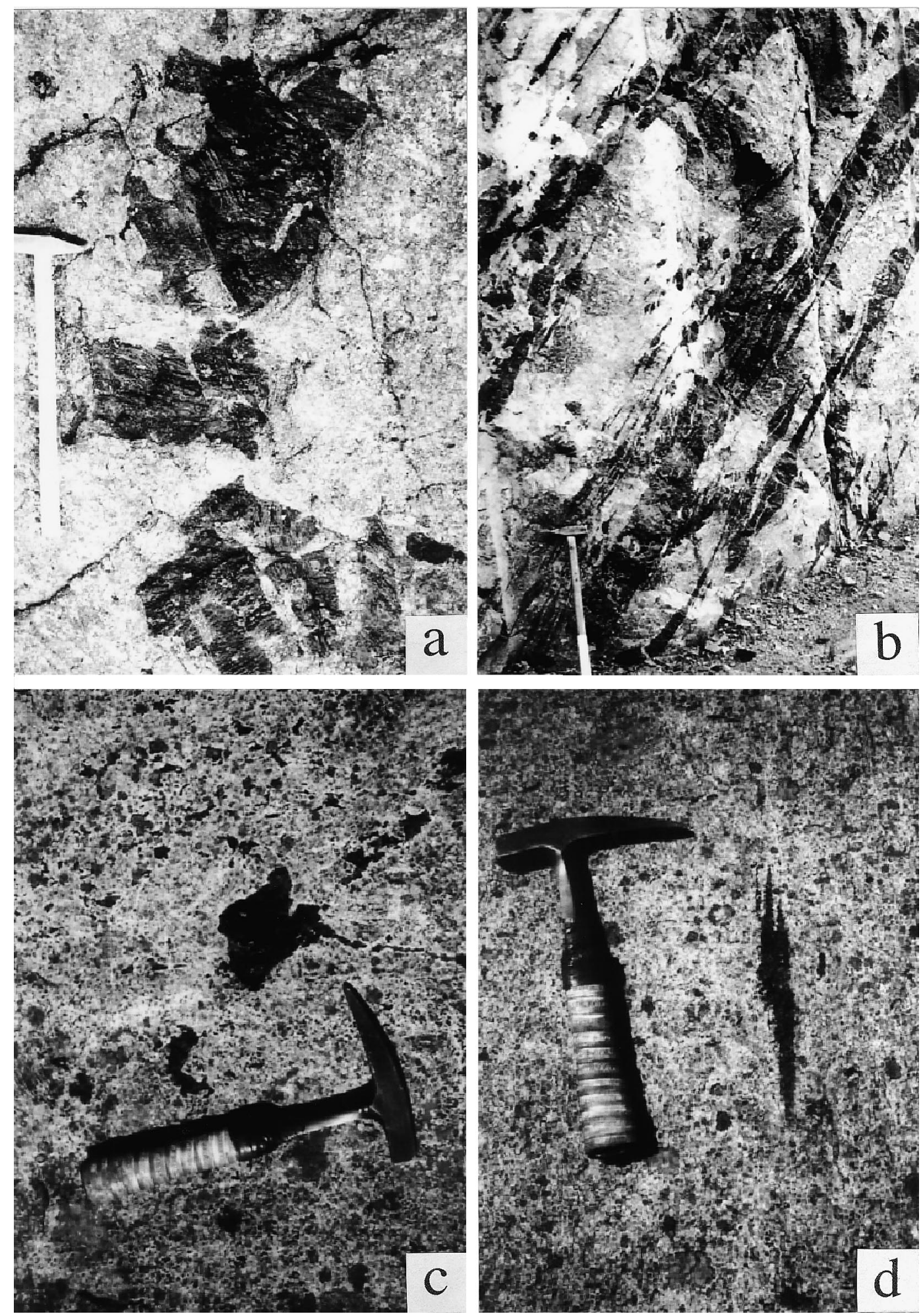
anorthosite massifs, EGOG massif, the HålandHelleren (HH), and the Åna-Sira (AS) bodies as well as a layered intrusion: the Bjerkreim-Sokndal massif (BKSK) (Michot and Michot, 1969; Duchesne, 1987a). These bodies were emplaced in migmatitic gneisses and have induced a large aureole of granulite facies thermal metamorphism (see the review by Maijer, 1987). Precise U-Pb dating (Schärer et al., 1996) clearly shows that all the anorthosite massifs intruded at $931 \pm 2 \mathrm{Ma}$, in a very short time interval (probably 2 m.y. or less), some 60 m.y. after the last pervasive regional deformation and imbrication of continental terranes. No shear zones of large amplitude or structures potentially favouring their emplacement have been recognized around the anorthosite province (Falkum, 1985). Anorthosite massifs thus appear in their pristine post-collisional or anorogenic state.

The EGOG massif (Fig. 1B), broadly circular (c. $20 \mathrm{~km}$ in diameter), is dome-shaped and shows a 13-km-thick inner margin of foliated leuconorite (Michot and Michot, 1969). In the north, the foliation is concordant both with the contact and with the foliation of migmatitic country gneisses. In the east, the foliated margin, dipping $80^{\circ} \mathrm{E}$, is separated from the BKSK intrusion by a continuous highly deformed norito-granitic screen. In the south, a similar, though discontinuous, screen - called the norito-granitic zone by Michot and Michot (1969) - separates the EGOG from the Håland massif, which is also foliated parallel to the contact. The southeastern tip of EGOG is truncated by the unfoliated Helleren massif. The EGOG foliation is generally steep (dipping at $60^{\circ}-90^{\circ}$ ) in the southern margin, whereas it dips at a lower angle $\left(35^{\circ}-65^{\circ}\right)$ in the northern contact with migmatitic gneisses.

Though monotonous at large, the central part of EGOG is made up of several varieties of anorthosite and leuconorite and shows a grossly concentric structure (Maquil and Duchesne, 1984; Duchesne and Maquil, 1987). A characteristic feature is the occurrence of high-alumina orthopyroxene megacrysts (HAOM) (see Fig. 2a) interstitial to plagioclase megacrysts. In the core of the massif they form aggregates (1-3 $\mathrm{m}$ in diameter) embedded in a medium-grained leuconorite or anorthosite matrix. HAOM can be slightly deformed (kinked), whereas the associated plagioclases are usually nearly completely granulated, phenoclasts being preserved only locally. HAOM typically show plagioclase exsolutions and their bulk composition contains up to $8 \%$ $\mathrm{Al}_{2} \mathrm{O}_{3}, 600-950$ ppm $\mathrm{Cr}$ (Duchesne and Maquil, 1987). They contrast with orthopyroxene (opx) from the matrix leuconorites $\left(<3 \% \mathrm{Al}_{2} \mathrm{O}_{3},<200 \mathrm{ppm} \mathrm{Cr}\right)$, pointing to lower pressure conditions of formation.

The marginal zone of EGOG is characterised by rocks similar to those in the central part but in various stages of deformation, from rare flow-oriented or layered structures to much recrystallized granoblastic texture, giving rise to banded anorthositic and leuconoritic gneisses. Numerous, huge, metre-sized HAOM are deformed and can stretch over several metres along the foliation (Fig. 2b). Granulation/recrystallization has been generated at temperatures between $980^{\circ} \mathrm{C}$ and $850^{\circ} \mathrm{C}$, according to two-pyroxene geothermometry (Maquil and Duchesne, 1984).

The BKSK layered intrusion flanks EGOG on the east (Michot and Michot, 1969; Duchesne, 1987b; Wilson et al., 1996) and has a syncline structure (Fig. 1A). Its lower part is made up of layered anorthosites, leuconorites and norites; its upper part contains granitoids. It contains at its base enclaves from the deformed margin of EGOG and its upper part yields zircon of $935 \pm 5 \mathrm{Ma}$ (Pasteels et al., 1979). It is thus subcontemporaneous with EGOG. A structural study (Paludan et al., 1994) has shown that folding of the massif has induced a mild penetrative deformation, producing a lineation converging towards the lowermost part of the syncline hinge zone, suggesting that these structures reflect gravity-induced subsidence.

\subsection{The petrological anorthosite model of formation}

Recent experimental data on the PT stability of HAOM (Longhi et al., 1993) have brought new ev-

Fig. 2. (a) Aggregate of plagioclase megacrysts and HAOM from the central part of the EGOG massif. The hammer is one metre long. (b) Foliated anorthosite in the inner margin of the EGOG massif with HAOM stretched along the foliation planes. The hammer is one metre long. (c) Small nearly undeformed HAOM. (d) Granulated/recrystallized (polygonized) HAOM from the margin. 

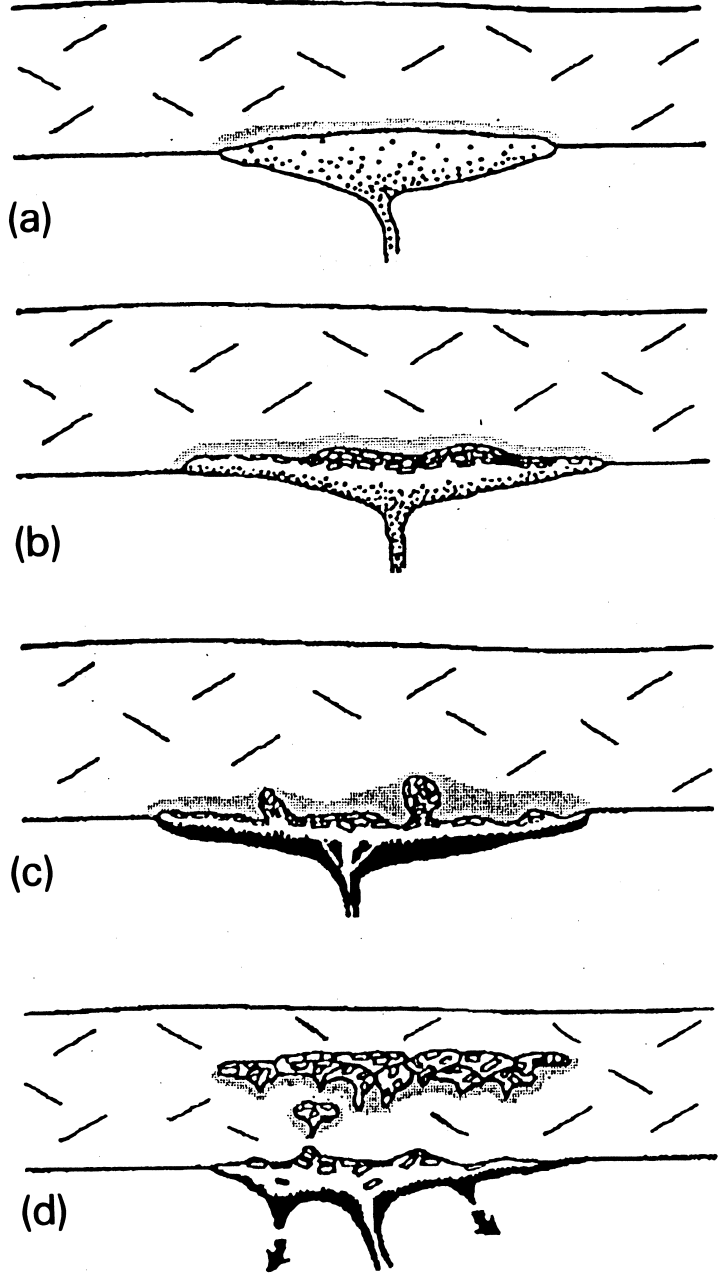

Fig. 3. The two-stage model for the generation of anorthosite massifs (after Ashwal, 1993). (a) A magma chamber develops at the base of the crust in which a basic magma starts crystallizing mafic minerals. (b) Mafic minerals sink and when plagioclase crystallizes it floats and accumulates at the top of the magma chamber. (c) Lumps of plagioclase-rich mush form and rise as diapirs through the lower crust. (d) Several diapirs coalesce at mid-crustal depth to make up anorthosite massifs. Stippled area: heat from the magma chamber causes partial melting of the crust.

idence in favour of the standard petrogenetic model which can be applied to the EGOG massif. In this model, as synthesized by Ashwal (1993) (Fig. 3), a broadly basaltic magma pounded and differentiated in a large pancake-shaped chamber at or near the base of the crust, around $1.2 \mathrm{GPa}$, from which aggregates of plagioclase megacrysts with rare inter- stitial HAOM crystallized, floated and accumulated at the roof of the chamber. Due to density inversion with the surrounding (partially melted) country rocks, masses of plagioclase with some entrained HAOM formed by gravity instability ascend through the crust as diapirs in anorogenic conditions. Coalescence of several diapirs at mid-crustal depths (around 0.5 GPa in Rogaland; Vander Auwera and Longhi, 1994) gives rise to anorthosite massifs. During ascent, the plagioclase crystal mush is lubricated by noritic melts from which low $\mathrm{Al}$ and $\mathrm{Cr}$ orthopyroxene crystallize at the final stage of intrusion.

More specific features are typically illustrated in the EGOG case (Duchesne et al., 1985; Duchesne and Maquil, 1987) and provide important parameters to constrain the diapiric emplacement model (see below). Aggregates of megacrysts were stuck along the margins of the diapir, and because of its highly crystalline nature, the mush moved as a rheological solid, causing internal stresses and producing granulation/recrystallization of plagioclase everywhere in the massif, and particularly in the margin where HAOM were also involved in the formation of the foliation. Upward rise of the diapir was greatly enhanced by partial melting of the surrounding migmatitic gneisses. Lateral expansion of the diapir took place when it reached a level of emplacement probably controlled by a strength increase in the upper crust, to give the massif its final pancake shape. This expansion could be partly responsible for ductile deformation of the margin and country rocks. Because it has remained in pristine state, EGOG thus constitutes an excellent case to address the structural record of diapirism and final lateral expansion. Occurrence of relicts of highpressure minerals such as HAOM documents the deep-seated episode of crystallization, and therefore attests the vertical movement of the crystal mush. Granulation/recrystallization of plagioclase is good evidence of the movement of a rheologically solid crystal mush. The high-temperature interval of crystallization $\left(1100^{\circ}-1275^{\circ} \mathrm{C}\right)$ constrained by experiments (Longhi et al., 1993) allows a large degree of contact anatexis of surrounding rocks and makes the ascent easier (Marsh, 1982). Though large discontinuities in the crust (Scoates and Chamberlain, 1997) might channel and facilitate the emplacement 
of some anorthosite massifs, no evidence of such structure is found in Rogaland, but part of the complex extends under the sea (Fig. 1A).

\section{Strain data}

Although some limited deformation is observed in the centre of EGOG, the higher strain intensities are located in the inner margin. The later displays several deformational features commonly found in plutons, such as foliation, deformed crysts, shear zones and folds. A strong strain gradient is observed from the massif boundary towards the centre. As mentioned above, the petrology and the observed structures support deformation in the solid state at the pluton boundary.

Strain analyses have been performed on outcrops at 51 sites, mainly within the foliated inner margin. HAOM and plagioclase megacrysts have been used as strain markers to determine the shape and orientation of the finite strain ellipsoid. At each site, sections across the deformed crystals were studied on one to four different outcropping surfaces, depending on the local topography. On one specific outcropping surface, the cryst sections present a sub-elliptical shape whose great axis has usually a constant orientation (Fig. 2d). For each surface a mean ellipticity has been computed from the shape measurements of up to 30 crystal sections. More than 1500 ellipses were measured in this study. At each site, a finite strain ellipsoid was then calculated from the orientation and ellipticity of ellipses observed on different surfaces. We used the program developed by Ratschbacher et al. (1994) from the method proposed by Milton (1980) to fit a strain ellipsoid to three different elliptical sections. Due to the lack of multiple surface exposures at many sites, only eight ellipsoids were constructed with Milton's method. Taking into account the foliation orientation, we also computed fourteen ellipsoids from ellipses in two different planes. Finally, strain ellipses were determined at 29 sites on planes perpendicular to the foliation, using singular mean-ellipses on arbitrarily oriented planes. The reliability of the results provided by the last two methods was checked on the eight sites with three or more elliptical sections. The $X Z$ sections of the ellipsoids are generally well ap- proximated by the last two methods and the whole set of results may be considered as coherent.

The method used in this study relies on two severe assumptions. Firstly, it is assumed that orthopyroxene deforms isotropically, which might not be the case because of their strong [100] parting. If the cryst is properly oriented, this parting can act as slip planes allowing extensive deformation. It is indeed not uncommon to find on the same outcrop a HAOM cryst showing a much larger ellipticity than the average of the other crysts. Such crysts have been discarded in the averages. Secondly, the initial shapes of the crysts used as markers are certainly not spheres (Fig. 2c), and there are clear limitations in estimating absolute finite strain ellipsoids from shape ratios of HAOM and plagioclase crysts. During ascent in the magma mush and their emplacement, these crysts have been affected by a solid-state deformation, as shown by the plagioclase and HAOM granulation observed in the bulk of the pluton. A limited deformation study in the centre of the massif has shown a faint sub-horizontal foliation. Inside this plane, the shape ratio $R_{x y}$ measured on crysts is less than 2, while $R_{x z}$ can reach a maximum of 3 . With these values in mind, the analysis of orthopyroxene and plagioclase markers presented here is based on the spatial variation of their shape rather than on their absolute strain. Indeed, in spite of the limitations mentioned before, cryst shape analysis has provided useful insights on strain patterns and variations within the massif.

Results of the strain analysis are presented in Table 1 . The type and intensity of the strain are expressed by the $k$ - and $d$-values of the strain ellipsoid (Ramsay and Huber, 1983) following:

$$
\begin{aligned}
& k=\frac{\left(R_{x y}-1\right)}{\left(R_{y z}-1\right)} \\
& d=\sqrt{\left(R_{x y}-1\right)^{2}+\left(R_{y z}-1\right)^{2}}
\end{aligned}
$$

where $R_{x y}$ and $R_{y z}$ are the ratios of the finite strain ellipsoid axes.

Fig. 4 maps horizontal ellipse sections ( $X Z$ or $Y Z)$ and the strain rate distribution $\left(R_{x z}\right.$-values) in the marginal zones. In general, strong strain is confined to the border and decreases towards the central part of the massif. The highest strains $\left(R_{x z}>11\right.$ and 

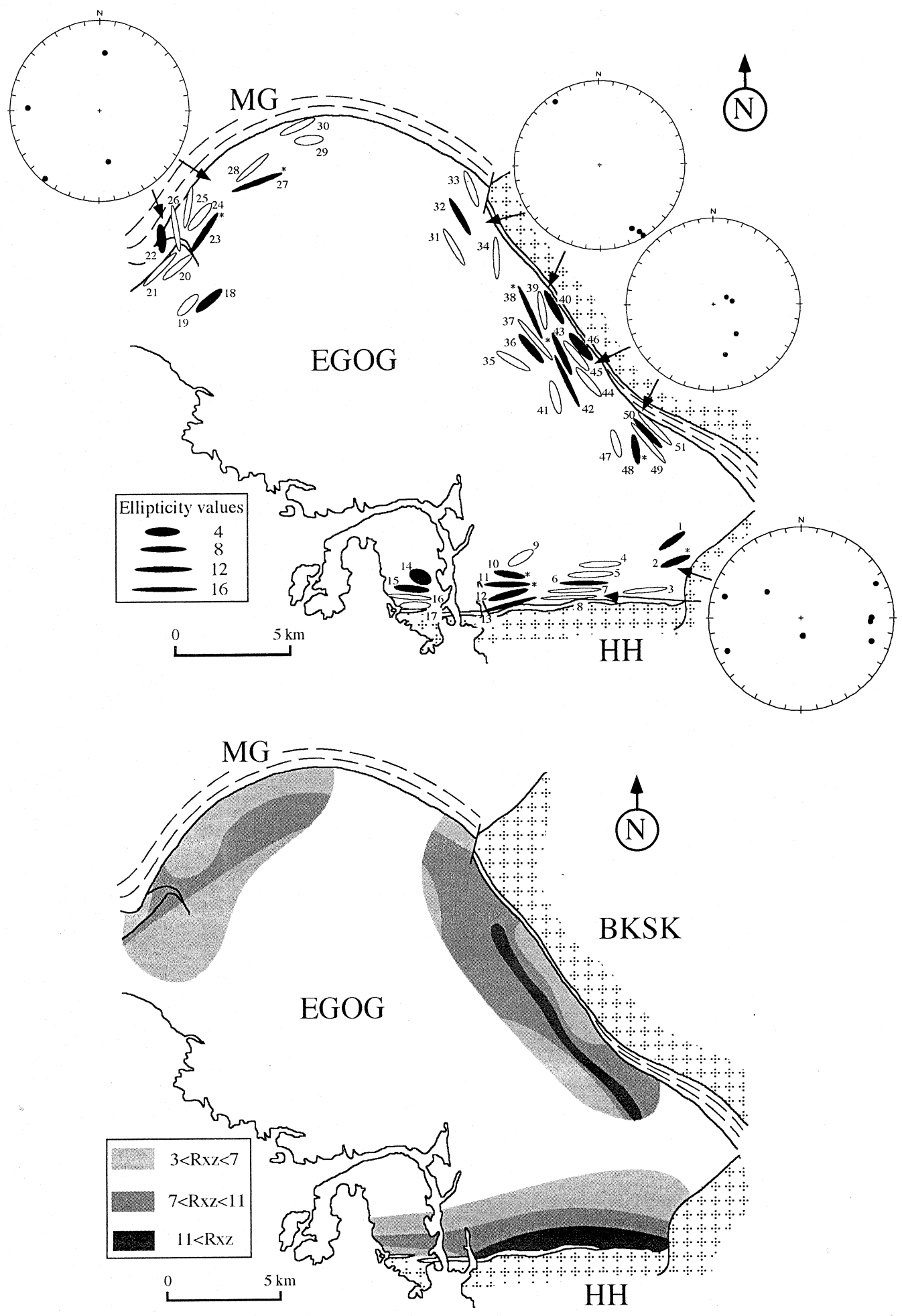
$d>5$ ) are found in the south and east, close to the adjacent magmatic intrusions (HH and BKSK). In the north and south, the cryst stretching ( $X$-axis) is generally sub-horizontal and parallel to the margin (Fig. 4a), and strain ellipsoids predominantly show oblate shape with $k$-values ranging between 0.0 and 0.7 . The $d$-values are intermediate to high (mainly between 1 and 5). Two ellipsoids show slight constriction $(k=1.5$ and 1.6). In the south, the maximal strain is located immediately near the contact and decreases towards the centre, whereas in the north and east, strain is generally more important at some distance from the contact $( \pm 1 \mathrm{~km}$, inside the eastern margin) (Fig. 4b). Along the border with the BKSK intrusion in the east, the strain intensity is high $\left(1.8<d<11\right.$ and $\left.5<R_{x z}<13\right)$ and $X$ plunge data show a horizontal elongation in the northern part, passing to a subvertical stretching in the southern part. In conclusion, the structural features and the strain pattern observed in the EGOG pluton are consistent with the petrological anorthosite model based on diapirism and late lateral expansion with a solid-state deformation. This model will now be tested by finite-element modelling.

\section{Finite-element modelling of the EGOG emplacement}

\subsection{Overview of previous modelling studies}

Diapirism has first been studied experimentally considering real fluid materials (Nettleton, 1934, 1943; Koyi, 1991). These studies highlighted the relation between diapir shape and viscosity ratio. Later experiments using clay and silicone models submitted to an increased gravity field (using centrifuge apparatus) have been performed by Ramberg (1967, 1981) and other authors (e.g. Talbot et al., 1991). In their experiments, the analysis was based on the study of the displacement field at the final stage, using destructive methods (usually a set of cross-sections). These experiments revealed the three-dimensional geometry of the diapiric phenomenon, which is comparable to a cellular pattern (Talbot et al., 1991). Numerous two-dimensional numerical simulations of diapirism have been performed in past studies, based on fluid mechanic description in which the fluids are considered as incompressible materials (Woidt, 1978; Schmeling, 1987; Zaleski and Julien, 1992). These models have led to conclusions similar to those of experiments about the viscosity ratio influence on the finite diapir shape. More recently, simulations based on solid mechanic description have been performed (see e.g. Poliakov et al., 1993). Most of these studies assume a plane strain condition. Recently, a complex modelling of salt diapirism including erosion and sedimentation processes has been presented by Poliakov et al. (1996) and has demonstrated the mechanical relevance of syn-sedimentary diapirism for salt rocks.

\subsection{Specificities of the method used in this study}

The test of the diapirism model is based on a purely mechanical analysis carried out with the LAGAMINE finite-element (FE) code (Charlier, 1987; Barnichon, 1998). This code uses an implicit resolution method (based on Newton-Raphson iterations) of the equilibrium equations, which ensures the correctness of the computed (approximated) solution. Large strains, displacements and rotations are accounted for through an updated Lagrangian formulation of the kinematic and through the use of the Jaumann objective stress rate. A more general description of the non-linear finite-element method can be found in Zienkiewicz and Taylor (1989).

The present FE code is coupled with an automatic adaptive re-meshing algorithm (Barnichon, 1998), in order to avoid large distortion of the mesh resulting from very important material flow. This re-meshing procedure is automatically activated when a given

Fig. 4. (a) Map of subhorizontal $X Z$ - or $Y Z$-sections. Filled ellipses are true $X Z$-sections, computed from the analysis of two or more outcrop surfaces. The ellipses marked with an asterisk have been obtained from at least three different surfaces. Empty ellipses are computed with a singular mean elliptic section on a horizontal surface. Equal-area, lower-hemisphere projections of $X$-axis orientations are plotted for the four indicated zones. (b) Map of strain ratio distribution along the EGOG margin $\left(R_{x z}\right.$-values). Investigated areas are darkened according to the strain intensity. Abbreviations: $M G=$ migmatitic gneisses; others as in Fig. 1. 
Table 1

Results of strain analyses

\begin{tabular}{|c|c|c|c|c|c|c|c|c|c|}
\hline Location & $n$ & $n_{\mathrm{s}}$ & $X Y$ & $X$ & $X / Y$ & $X / Z$ & $Y / Z$ & $k$ & $d$ \\
\hline \multicolumn{10}{|c|}{ Southern margin } \\
\hline 1 & 15 & 2 & $145 / 50$ & $065 / 12$ & 1.8 & 3.8 & 2.1 & 0.7 & 1.4 \\
\hline 2 & 34 & 3 & $160 / 75$ & $246 / 14$ & 1.8 & 4.0 & 2.2 & 0.7 & 1.4 \\
\hline 3 & 22 & 1 & $182 / 48$ & & & 10.8 & & & \\
\hline 4 & 9 & 1 & $173 / 50$ & & & 8.5 & & & \\
\hline 5 & 13 & 1 & $173 / 65$ & & & 9.6 & & & \\
\hline 6 & 46 & 2 & $180 / 50$ & $108 / 21$ & 2.9 & 10.8 & 4.8 & 0.5 & 4.2 \\
\hline 7 & 10 & 1 & $175 / 45$ & & & 15.7 & & & \\
\hline 8 & 12 & 1 & $180 / 75$ & & & 17.4 & & & \\
\hline 9 & 9 & 1 & $180 / 83$ & & & 4.7 & & & \\
\hline 10 & 8 & 3 & $015 / 82$ & $286 / 16$ & 1.4 & 4.2 & 3.0 & 0.2 & 2.0 \\
\hline 11 & 21 & 3 & $185 / 90$ & $093 / 26$ & 3.4 & 8.9 & 2.6 & 1.5 & 2.9 \\
\hline 12 & 17 & 2 & $160 / 75$ & $174 / 74$ & 1.6 & 9.7 & 5.9 & 0.1 & 5.0 \\
\hline 13 & 22 & 2 & $170 / 70$ & $090 / 25$ & 1.8 & 15.1 & 8.4 & 0.1 & 7.4 \\
\hline 14 & 24 & 2 & $000 / 83$ & $300 / 76$ & 1.0 & 3.6 & 3.6 & 0.0 & 2.6 \\
\hline 15 & 10 & 2 & $033 / 78$ & $308 / 52$ & 1.7 & 2.4 & 1.4 & 1.6 & 0.8 \\
\hline 16 & 8 & 1 & $180 / 85$ & & & 9.5 & & & \\
\hline 17 & 6 & 1 & $180 / 85$ & & & 3.7 & & & \\
\hline \multicolumn{10}{|c|}{ Northern margin } \\
\hline 18 & 18 & 2 & $322 / 45$ & $005 / 36$ & 1.6 & 4.2 & 2.5 & 0.4 & 1.7 \\
\hline 19 & 11 & 1 & $320 / 70$ & & & 2.8 & & & \\
\hline 20 & 9 & 1 & $320 / 80$ & & & 5.4 & & & \\
\hline 21 & 8 & 1 & $315 / 60$ & & & 8.4 & & & \\
\hline 22 & 17 & 2 & $260 / 90$ & $170 / 42$ & 2 & 3.2 & 1.6 & 1.5 & 1.2 \\
\hline 23 & 16 & 3 & $305 / 38$ & $219 / 04$ & 1.5 & 7.5 & 4.9 & 0.1 & 3.9 \\
\hline 24 & 8 & 1 & $308 / 70$ & & & 3.8 & & & \\
\hline 25 & 2 & 1 & $280 / 77$ & & & 5.3 & & & \\
\hline 26 & 9 & 1 & $260 / 40$ & & & 8.4 & & & \\
\hline 27 & 33 & 3 & $341 / 46$ & $273 / 21$ & 1.9 & 10.9 & 5.8 & 0.2 & 4.9 \\
\hline 28 & 19 & 1 & $320 / 33$ & & & 7.4 & & & \\
\hline 29 & 12 & 1 & $355 / 68$ & & & 3.1 & & & \\
\hline 30 & 12 & 1 & $335 / 45$ & & & 5.1 & & & \\
\hline \multicolumn{10}{|c|}{ Eastern margin } \\
\hline 31 & 9 & 1 & $060 / 60$ & & & 6.8 & & & \\
\hline 32 & 16 & 2 & $065 / 60$ & $150 / 09$ & 1.3 & 7.0 & 5.4 & 0.1 & 4.4 \\
\hline 33 & 8 & 1 & $076 / 55$ & & & 4.8 & & & \\
\hline 34 & 30 & 1 & $085 / 50$ & & & 6.9 & & & \\
\hline 35 & 6 & 1 & $030 / 56$ & & & 4.7 & & & \\
\hline 36 & 18 & 2 & $055 / 85$ & $326 / 09$ & 2.4 & 5.1 & 2.2 & 1.2 & 1.8 \\
\hline 37 & 7 & 1 & $055 / 58$ & & & 10.6 & & & \\
\hline 38 & 30 & 3 & $071 / 65$ & $154 / 17$ & 8 & 13.4 & 1.7 & 10.4 & 7.0 \\
\hline 39 & 15 & 1 & $085 / 63$ & & & 5.6 & & & \\
\hline 40 & 11 & 2 & $060 / 55$ & $149 / 02$ & 2.3 & 5.0 & 2.2 & 1.1 & 1.8 \\
\hline 41 & 8 & 1 & $075 / 85$ & & & 3.3 & & & \\
\hline 42 & 30 & 2 & $065 / 60$ & $340 / 08$ & 1.0 & 12.2 & 11.9 & 0.0 & 10.9 \\
\hline 43 & 9 & 3 & $245 / 76$ & $167 / 40$ & 3.7 & 8.2 & 2.2 & 2.2 & 3.0 \\
\hline 44 & 8 & 1 & $055 / 57$ & & & 4.7 & & & \\
\hline 45 & 16 & 1 & $053 / 65$ & & & 5.6 & & & \\
\hline 46 & 28 & 2 & $048 / 72$ & $094 / 65$ & 1.5 & 5.7 & 3.9 & 0.2 & 2.9 \\
\hline 47 & 9 & 1 & $070 / 70$ & & & 4.2 & & & \\
\hline 48 & 22 & 3 & $070 / 75$ & $142 / 55$ & 5.2 & 22.0 & 4.3 & 1.3 & 5.3 \\
\hline 49 & 15 & 1 & $045 / 70$ & & & 9.8 & & & \\
\hline 50 & 24 & 2 & $045 / 75$ & $079 / 72$ & 1.1 & 8.3 & 7.4 & 0.0 & 6.4 \\
\hline
\end{tabular}

$n$ : number of measurements; $n_{\mathrm{s}}$ : number of different surfaces at each outcrop; $X Y$ : dip of the $X Y$-plane; $X$ : plunge of the ellipsoid great axis; $X / Y, X / Z$ and $Y / Z$ are the ratios of the strain ellipsoid; $k$ and $d$ values of the strain ellipsoid. 
ratio of overdistorted elements is reached, following Habraken (1989). The high level of automation of this procedure easily allows the user to perform computations with very large strains/displacements. The re-meshing algorithm has been designed to deal with complex multidomain geometries and is therefore not restricted to the type of geometries considered here. In addition, artificial passive markers have been introduced to follow the distortion through the re-meshing phases (Barnichon, 1998).

In the present study, both fluid-like and solid-like behaviours have been considered depending on the depth. The upper crust behaves as a solid, whereas the deeper part of the crust - i.e. the lower granitic crust and the noritic crust - exhibits a viscous behaviour closer to a fluid. In this framework, an advantage of a solid mechanic over a fluid mechanic formulation lies in the ability of the first one to represent both behaviours, provided the materials exhibit some compressibility. Therefore, viscous solid and elastoplastic behaviours have been used together, as detailed in the next section.

\subsection{Model}

As already mentioned in Section 2, the study of EGOG provides good constraints on the geometry and timing of emplacement.

\subsubsection{Constraints}

The depth of the initial magma chamber is constrained by the stability of HAOM at about $1.2 \mathrm{GPa}$, while the final emplacement pressure of Rogaland anorthosites is likely to be close to $0.5 \mathrm{Gpa}$. The petrological model exposed above assumes that the diapir moved upward across the whole lower crust (noritic composition) and that emplacement stopped at the limit between the upper crust (granitic composition) and the lower crust. The density of the upper crust is considered equal to the granite one, i.e. $d \approx 2.7$, and the density of the lower crust falls in the range $3.0<d<3.2$ (Hall, 1986). It follows from these pressure estimates and density values that the lower crust extends approximately from $40 \mathrm{~km}$ to $18 \mathrm{~km}$ depth, and that the upper crust has a thickness of $18 \mathrm{~km}$. Although the density of the plagioclase megacrysts $\left(\mathrm{An}_{50}\right)$ at $1200^{\circ} \mathrm{C}$ falls in the range $2.63<d<2.65$ (Campbell et al.,
1978), a conservative density value of $d=2.75$ has been adopted here for the anorthosite crystal mush, considering that some liquid (corresponding to 18 to $32 \%$ in volume) of higher density (lower crust) may have been entrapped in the mush. The initial anorthosite cumulate at the roof of the deep-seated chamber is represented by an infinite horizontal layer with a thickness of $2 \mathrm{~km}$ to $5 \mathrm{~km}$ and located at 40 $\mathrm{km}$ depth. Based on these assumptions, a lithological profile (Fig. 5a) has been adopted. A value of 2 m.y. has been chosen for the timing of emplacement.

\subsubsection{Constitutive laws for the continental crust}

The rheology of the layered structure presented in Fig. 5a has now to be evaluated. As proposed by Davy and Cobbold (1991), two main flow mechanisms have been considered for the crust.

The first one is a time-independent brittle behaviour (Byerlee, 1978), which is usually considered to follow Mohr-Coulomb's plastic criterion:

$\frac{\sigma_{1}-\sigma_{3}}{2}=c+\frac{\sigma_{1}+\sigma_{3}}{2} \tan \phi$

where $c$ is the cohesion and $\phi$ the friction angle. Here the values $\phi=37^{\circ}$ and $c=0$ have been adopted. In numerical applications, this behaviour will be approximated by an elastoplastic law based on a Drücker Prager yield criterion $f$, modified following Van Eekelen (1980):

$f=I I_{\hat{\sigma}}+m\left(I_{\sigma}-\frac{3 c}{\tan \phi}\right)=0$

where $\hat{\sigma}, I_{\sigma}$ and $I I_{\hat{\sigma}}$ represent the stress deviator, the first stress invariant and the second deviatoric stress invariant, respectively. They are defined by (where the convention summation applies to all repeated indices, and $\delta_{i j}$ is the Kronecker delta):

$\hat{\sigma}_{i j}=\sigma_{i j}-\frac{I_{\sigma}}{3} \delta_{i j}$,

$\delta_{i j}= \begin{cases}1 & \text { if } \quad i=j \\ 0 & \text { if } \quad i \neq j\end{cases}$

$I_{\sigma}=\sigma_{k k}$

$I I_{\hat{\sigma}}=\sqrt{\frac{1}{2} \hat{\sigma}_{i j} \hat{\sigma}_{i j}}$

In Eq. 4), coefficient $m$ depends on the third deviatoric stress invariant in order to closely match 


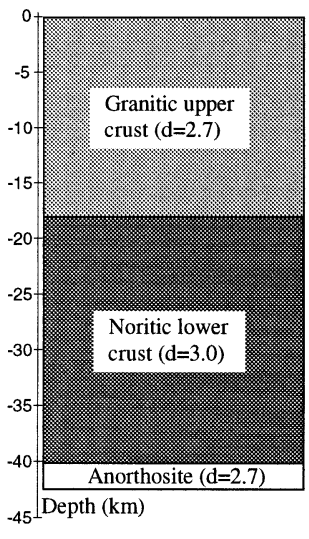

a)

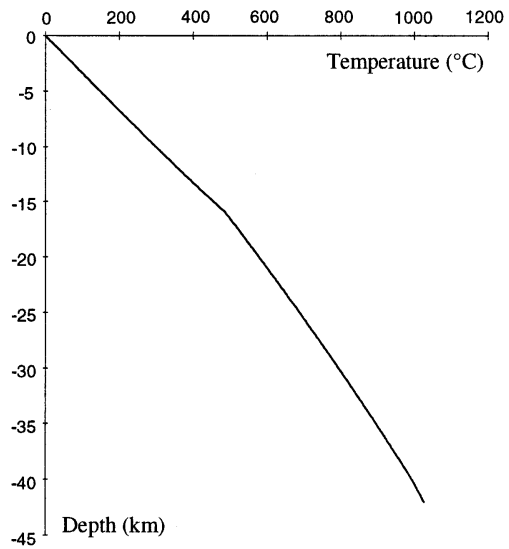

b)

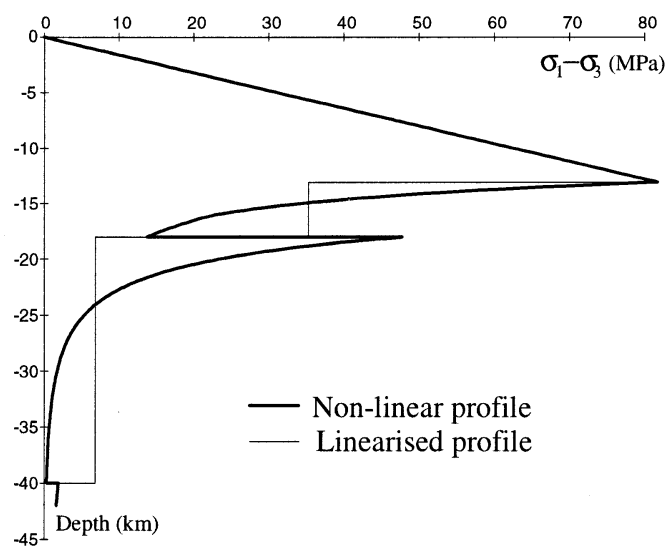

c)

Fig. 5. Different steps in the computation of a rheological profile for the crust: (a) choice of a lithological profile; (b) choice of a geothermal profile (from Chapman, 1986); (c) computation of a non-linear rheological profile for $\dot{\varepsilon}=10^{-13} \mathrm{~s}^{-1}$ and linearization of the viscous parts following Davy and Cobbold (1991).

the Mohr-Coulomb criterion given in Eq. 3 (see Barnichon and Charlier, 1996, and Barnichon, 1998, for the detailed formulation of $m$ ). A non-associated and perfectly plastic law is assumed.

The second mechanism is a time-dependent viscous behaviour obeying a power law:

$\dot{\hat{\varepsilon}}=A \exp \left(-\frac{Q}{R T}\right) \hat{\sigma}^{n}$

which links the deviatoric stress tensor $\hat{\sigma}$ to the deviatoric strain rate tensor $\dot{\hat{\varepsilon}}$ (Carter and Tsenn, 1987). In this relation, $Q$ is the activation energy of creep, $R$ the gas constant, $T$ the absolute temperature, $A$ and $n$ material constants. Such non-linear behaviour is obviously temperature-dependent. Values for these parameters for a broad range of minerals and rocks have been reported in Carter and Tsenn (1987) (Table 2). As a first approximation, a linear Newtonian behaviour is considered here, i.e.

Table 2

Parameters of the power law (from Carter and Tsenn, 1987)

\begin{tabular}{llll}
\hline Rock or mineral type & $n$ & $\begin{array}{l}Q \\
(\mathrm{~kJ} \mathrm{~mole}\end{array}$ & $\begin{array}{l}A \\
\left(\mathrm{MPa}^{-\mathrm{n}} \mathrm{s}^{-1}\right)\end{array}$ \\
\hline Westerly granite (dry) & 3.3 & 186.5 & -5.7 \\
Maryland diabase (dry) & 3.05 & 276 & -1.2 \\
Hale albite (dry) & 3.9 & 234.2 & -5.63 \\
\hline
\end{tabular}

exponent $n=1$ in Eq. 6, which then simplifies to:

$\dot{\hat{\varepsilon}}=\frac{\hat{\sigma}}{\eta}$

provided the dynamic viscosity $\eta$ is defined by:

$\frac{1}{\eta}=A \exp \left(-\frac{Q}{R T}\right)$

The Newtonian behaviour will be approximated by an elastic-viscoplastic law for which the elastic domain is bounded by a Von Mises surface. In this model, the viscoplastic deviatoric strain rate $\dot{\hat{\varepsilon}}^{\text {vp }}$ is given by

$\dot{\hat{\varepsilon}}^{\mathrm{vp}}=\frac{B}{K} \hat{\sigma}$

where coefficient $B / K$ is equivalent to the inverse of viscosity and $K$ is the yield limit (equivalent to cohesion).

For both elastoplastic and elastic-viscoplastic laws, the volumic part of the behaviour follows Hooke's law:

$\dot{\sigma}_{\mathrm{m}}=\chi \dot{\varepsilon}_{\mathrm{m}}$

where the elastic compressibility modulus $\chi$ can be expressed as a function of Young modulus $E$ and Poisson ratio $v$ following:

$\chi=\frac{E}{3(1-2 v)}$ 
From the two flow behaviours presented above (Mohr-Coulomb and power law), corresponding rheological profiles can be computed provided additional assumptions are made: a steady state thermal field is considered (Fig. 5b) following Chapman (1986), and an homogeneous strain rate is assumed throughout the considered domain. In the present case, the strain value is approximated by assuming that the initially 2-km-thick anorthosite layer will flow upward through the lower crust $(22 \mathrm{~km}$ thickness), which gives an approximate strain value $\varepsilon=22 / 2=11$. Assuming that the emplacement took place in about 2 m.y. leads to the strain rate $\dot{\varepsilon}$ :

$\dot{\varepsilon}=\frac{11}{2\left(3.15 \times 10^{12}\right)} \approx 1.7 \times 10^{-13} \mathrm{~s}^{-1}$

A rounded strain rate value of $10^{-13} \mathrm{~s}^{-1}$ has been retained as a rough approximation. Moreover, the tectonic regime must be defined (Sibson, 1974) in order to assess which of the principal stress components is closer to the vertical. As detailed in a previous section, the emplacement of EGOG anorthosite is not linked to any orogen and thus occurred without regional tectonic stresses. In such situation, the major principal stress is likely to be vertical $\left(\sigma_{1}=\sigma_{\mathrm{v}}\right)$, which corresponds to an extensional domain. Note, however, that, provided the horizontal stress $\sigma_{\mathrm{h}}$ is close to $\sigma_{\mathrm{v}}$, an almost isotropic stress state may also be considered. From these assumptions, the rheological profile is computed according to the method presented in Davy and Cobbold (1991) using the power law parameters given in Table 2. The obtained rheological profile, presented in Fig. 5c, allows to distinguish between one brittle and two viscous domains for the crust, and to estimate an equivalent linear viscosity for each viscous domain (reported in Table 3). It must be kept in mind that these values only give the order of magnitude of linear viscosities, provided that all assumptions are roughly verified.

Table 3

Rock linear viscosities obtained for $\dot{\varepsilon}=10^{-13} \mathrm{~s}^{-1}$

\begin{tabular}{ll}
\hline Rock or mineral type & $\eta$ \\
& $($ Pa s) \\
\hline Westerly granite (dry) & $3.5 \times 10^{20}$ \\
Maryland diabase (dry) & $6.8 \times 10^{19}$ \\
Hale albite (dry) & $1.8 \times 10^{19}$ \\
\hline
\end{tabular}

\subsubsection{Initial geometry, boundary conditions}

The number of layers and their respective depth (Fig. 6a) are defined from the rheological profile given on Fig. 5c: the granitic upper crust is divided into an elastoplastic part (from $-13 \mathrm{~km}$ to $0 \mathrm{~km}$ depth) and a viscous part (from $-18 \mathrm{~km}$ to $-13 \mathrm{~km}$ depth). The whole lower crust (from $-40 \mathrm{~km}$ to -18 $\mathrm{km}$ depth) and the anorthosite layer are both viscous.

The problem is studied in two dimensions under axisymmetrical conditions (symmetry of revolution around the vertical axis - see Fig. 6b). The upper surface is a free surface and a frictionless basal boundary condition is considered to be a reasonably good approximation for the floor of the deep-seated magma chamber. The lateral boundaries are also frictionless and fixed in the horizontal direction. Due to density inversion between anorthosite $(d=2.75)$ and lower crust $(d=3.0)$, the mechanical state is metastable, and an initial perturbation is required to trigger the upwelling mechanism. Here we have chosen a geometrical perturbation (a 300-m deflection along the vertical direction located close to the symmetry axis) at the interface between the anorthosite layer and the lower crust, which therefore is not perfectly flat. The loading purely consists of body forces applied following the vertical direction. A balanced state of stress must be initialised in the model prior to computation. According to the viscous behaviour (in which equilibrium requires no stress deviator) and to the gravity forces (for which equilibrium requires a lithostatic stress state), the only balanced initial state verifying equilibrium corresponds to an isotropic lithostatic stress state, i.e., at each point, $\sigma_{1}=\sigma_{2}=\sigma_{3}=\rho g h$, where $\rho$ is the average specific mass of the considered rock column, $h$ its height and $g$ the gravity acceleration. Three horizontal passive markers are introduced in the anorthosite layer and in the lower crust layer (dashed lines on Fig. 6b) in order to follow the distortion through re-meshing procedures. From a practical point of view, each simulation requires between 4 and $6 \mathrm{~h}$ CPU time on a DEC ALPHA workstation, including about ten re-meshing phases. It must be noted that the CPU time required for re-meshing is negligible compared to the time required for system resolution (less than $5 \%$ ). 


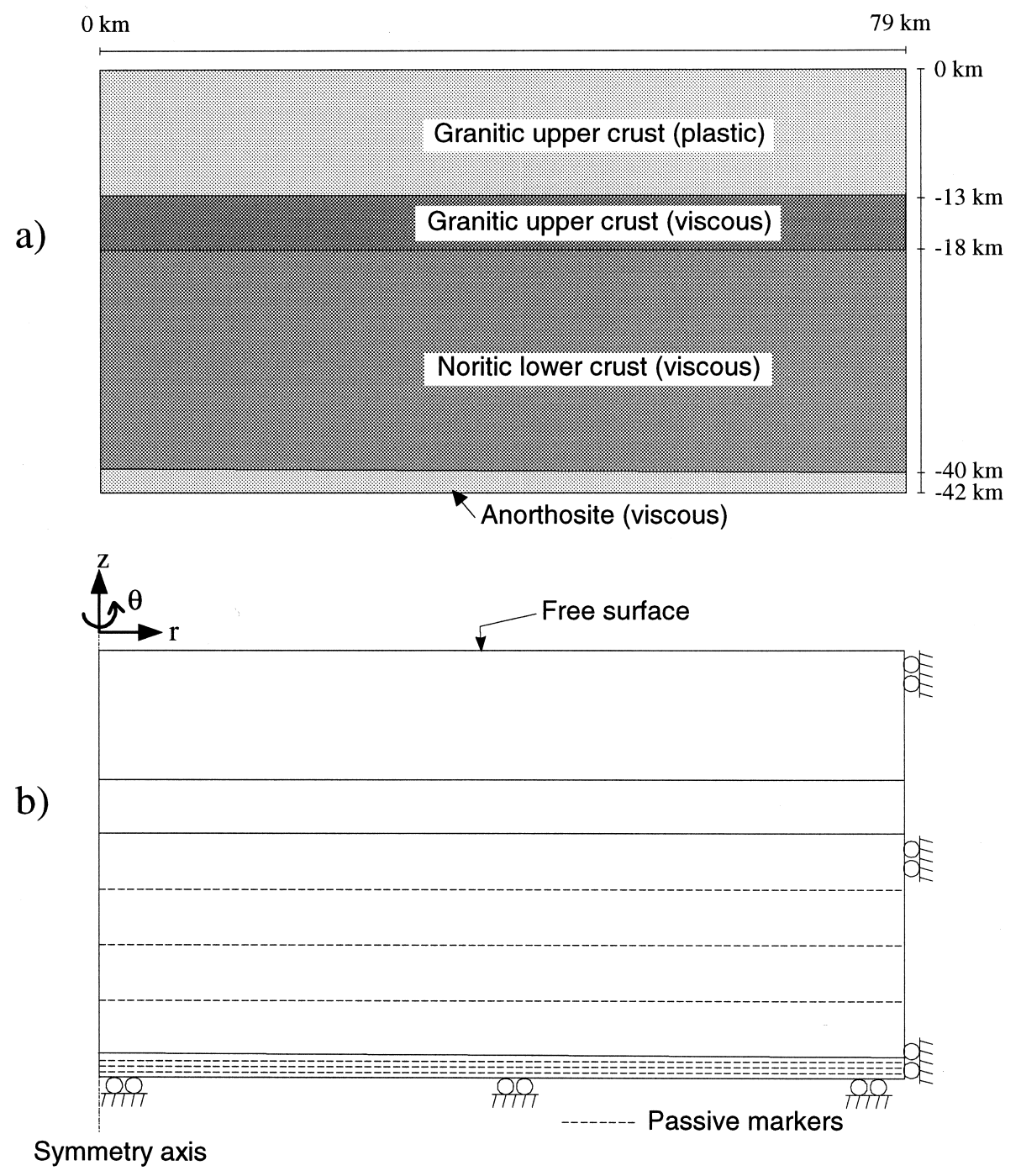

Fig. 6. (a) Geometry of the basic model. (b) Boundary conditions of the basic model.

\section{Modelling results}

In Section 5.1, a first model is described in detail, and some variants around this basic model are presented in Section 5.2.

\subsection{Basic model}

Rheological and geometrical parameters considered for this model are reported in Table 4 (see also Fig. 6a). The lower crust is 3.8 times more viscous than the anorthosite layer ( $2 \mathrm{~km}$ thick). The evolution of the geometry, the velocity field and the strain field are presented on Figs. 7-9 for the initiation, amplification and damping phases, respectively. Note that for each phase, the finite strain tensor (noted $e$ ) is computed between the two geometries given in (a) of Figs. 7-9, and thus is not the global finite strain tensor from the initial configuration at $t=0 \mathrm{~m}$.y. to the final one. The mechanic convention sign is used for strains, i.e. negative values indicate compression, whereas positive ones indicate extension.

During the initiation phase, the anorthositic material rises up and a major clockwise 'convection' cell 
Table 4

Mechanical parameters for the basic model

\begin{tabular}{|c|c|c|c|c|c|c|c|c|}
\hline Layer & $\begin{array}{l}E \\
(\mathrm{GPa})\end{array}$ & $v$ & $\begin{array}{l}\phi \\
\left({ }^{\circ}\right)\end{array}$ & $\begin{array}{l}c \\
(\mathrm{MPa})\end{array}$ & $\begin{array}{l}H \\
(\mathrm{~Pa})\end{array}$ & $\begin{array}{l}\eta \\
(\mathrm{Pa} \mathrm{s})\end{array}$ & $\begin{array}{l}\rho \\
\left(\mathrm{kg} \mathrm{m}^{-3}\right)\end{array}$ & $\begin{array}{l}\text { Thickness } \\
(\mathrm{km})\end{array}$ \\
\hline$>$ Granite & 10 & 0.24 & 37 & 0 & & & 2700 & 13 \\
\hline$<$ Granite & 10 & 0.24 & & & 100 & $3.5 \times 10^{20}$ & 2700 & 5 \\
\hline Norite & 10 & 0.24 & & & 100 & $6.8 \times 10^{19}$ & 3000 & 22 \\
\hline Anorthosite & 10 & 0.24 & & & 100 & $1.8 \times 10^{19}$ & 2750 & 2 \\
\hline
\end{tabular}

develops in the noritic layer close to the symmetry axis, as attested by the velocity field at $t=2.0 \mathrm{~m}$.y. (Fig. 7b). The term convection is used here for a mechanical phenomenon due to a density contrast, by analogy with the shape of a thermal convection cell. The deformed passive markers (Fig. 7c) indicate a quite continuous displacement field, the upper markers being almost non-deformed, and the anorthosite exhibiting a bell shape. Around the symmetry axis, the radial strain component $e_{\mathrm{r}}$ and the circumferential strain component $e_{\theta}$ denote a compression state (Fig. 7d,f), while the vertical strain component $e_{\mathrm{z}}$ indicates an extension state (Fig. 7e) which translates the vertical movement of material. Note that at any point the volumic strain is negligible compared to the deviatoric strain, i.e. $e_{\mathrm{r}}+e_{\theta}+e_{\mathrm{z}} \approx 0$. In the lower crust above the anorthosite bulb, all strain components are inverted and their intensity is lower. During this phase, the average rising velocity of the bulb apex reads $0.4 \mathrm{~cm} / \mathrm{yr}$.

At the end of the amplification phase, at $t=2.4$ m.y. (Fig. 8), the average rising velocity of the bulb reads $2.5 \mathrm{~cm} / \mathrm{yr}$, and the velocity intensity is multiplied by 3 compared to the value at the end of the previous phase. The velocity field (Fig. 8b) shows that the viscous part of the granitic crust clearly begins to be involved in the phenomenon, and also that a second (conjugate) convection cell with an anticlockwise rotation can now be identified at the periphery of the first one. The deformed passive markers (Fig. 8c) show a large displacement of material within the anorthosite bulb, which has generated a conjugate downward flow in the lower crust. Two opposite strain domains can be distinguished (Fig. 8d-f). The first one, located at the bulb base, is very similar to the one described during the initiation phase. The second strain domain affects both the anorthosite bulb apex and its cover, and the strain state is inverted compared to the first domain, i.e. $e_{\mathrm{r}}$ and $e_{\theta}$ are in extension, whereas $e_{\mathrm{z}}$ is in compression. Such strain state results from the radial and circumferential expansion of the bulb top part, also visible in Fig. 8a. Note that, as in the initiation phase, the $e_{\mathrm{r}}$ and $e_{\theta}$ extension values are almost equal near the apex.

In the damping phase, at $t=2.8 \mathrm{~m}$.y. (Fig. 9), the average rising velocity of the bulb apex decreases to $0.5 \mathrm{~cm} / \mathrm{yr}$, and, at the end of this phase, the rising velocity of the apex becomes almost nil. In other words, the vertical ascent of anorthosite material stops, which is likely to result from the inability of the diapir to penetrate the granitic crust, due to the higher viscosity of the later $\left(\eta=3.510^{20} \mathrm{~Pa} \mathrm{~s}\right)$ compared to the anorthosite $\left(\eta=1.810^{19} \mathrm{Pas}\right)$. Note, however, that this arrest may also be influenced by the boundary conditions of the model, which do not allow the disappearance of the norite layer above the bulb apex (as the norite thickness must remain finite) and of the anorthosite layer (which cannot be completely emptied). From the velocity field shown in Fig. 9b, two weak instabilities located in the middle and on the right boundary of the model clearly begin to be generated by additional convection cells, and correspond to the location of new bulbs. Because of the model axisymmetry, they actually develop as rings. However, the first bulb (close to the axis) can still be studied accurately. Within the lower crust, the conjugate downward flow is more pronounced (Fig. 9c), and the viscous part of the granitic crust is now frankly involved in the instability. Inside the anorthosite bulb, the two strain domains defined are still present (Fig. 9d-f). The second one, which is induced by the radial and circumferential expansion, is now centred within the bulb. The major difference between this damping phase and the previous ones comes from the circumferential extension which is now larger than the radial extension, i.e. $e_{\theta}>e_{\mathrm{r}}$, 


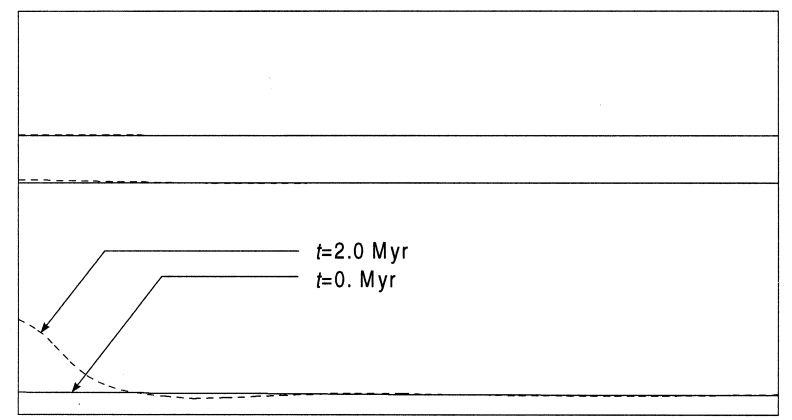

a)

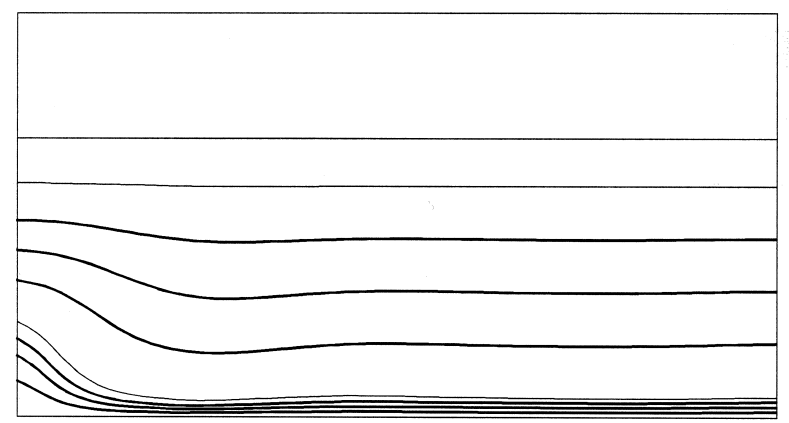

c)

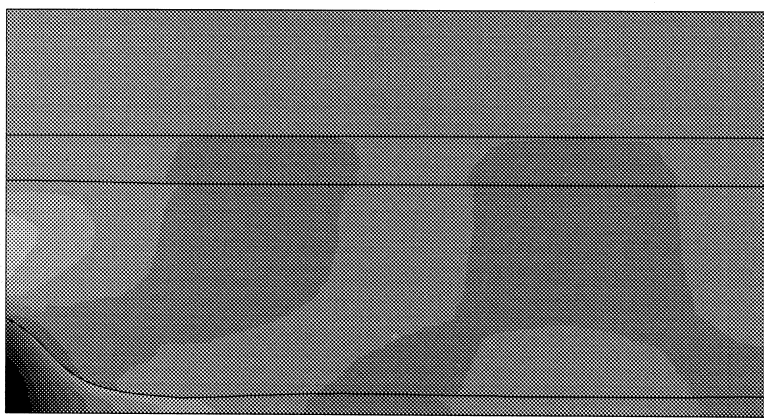

e)

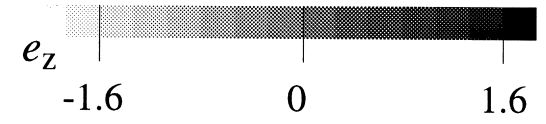

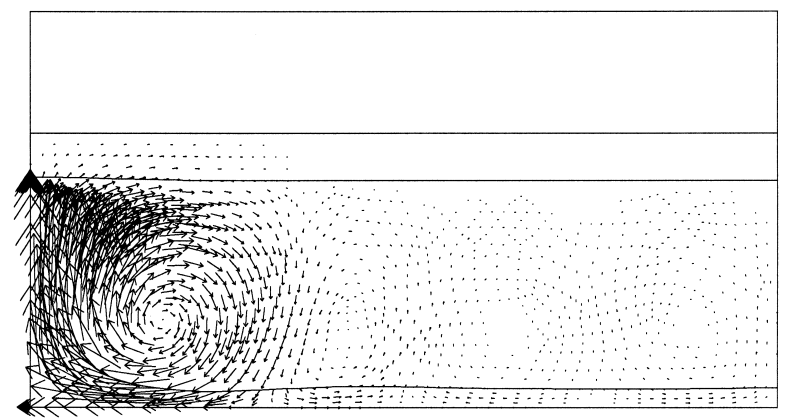

b)

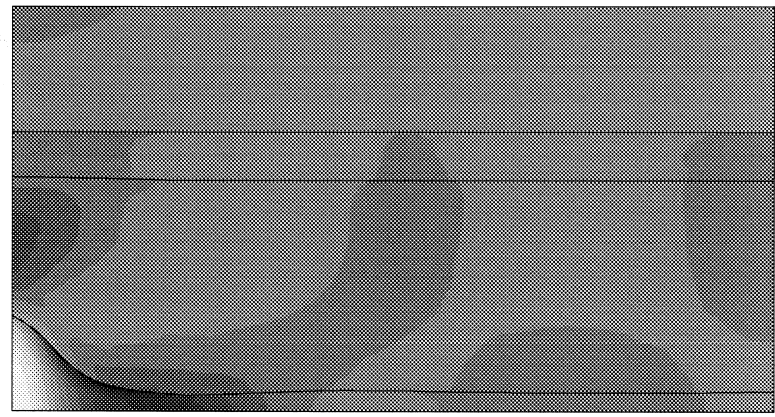

d)
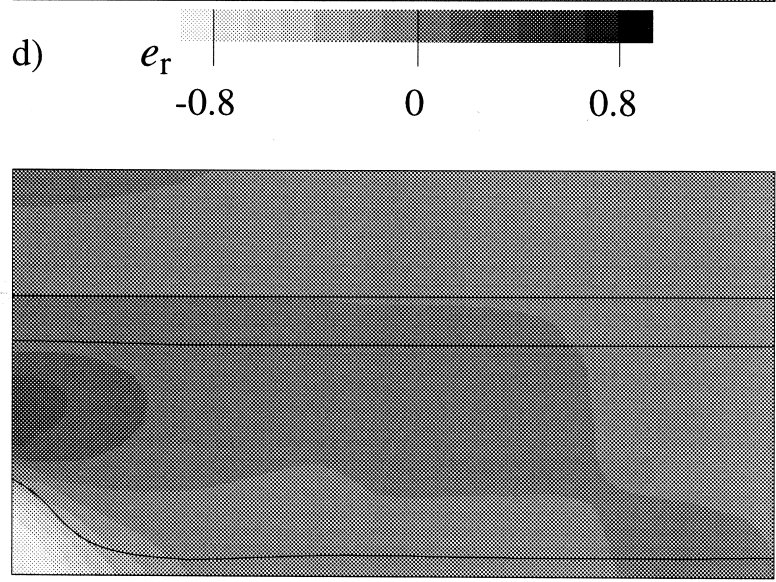

f)

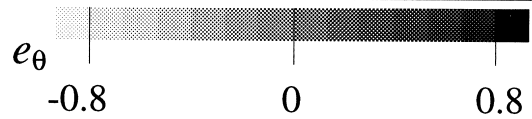

Fig. 7. Basic model initiation phase: (a) deformed geometry at $t=0$ m.y. (full line) and $t=2.0$ m.y. (dashed line); (b) velocities at $t=2.0$ m.y.; (c) passive markers (thick lines) at $t=2.0$ m.y.; (d, e, f) radial $e_{\mathrm{r}}$, vertical $e_{\mathrm{z}}$ and circumferential $e_{\theta}$ components of the strain tensor computed for the time range $0<t<2.0$ m.y. Negative values indicate compression.

whereas in the initiation and amplification phases these components were quite similar.

It is worth pointing out that the rigid upper crust is not involved in the instability and remains almost undeformed. Besides the strength difference between the crust layers, a reason may lie in the absence of an inverse density gradient between the upper crust and the anorthosite. 


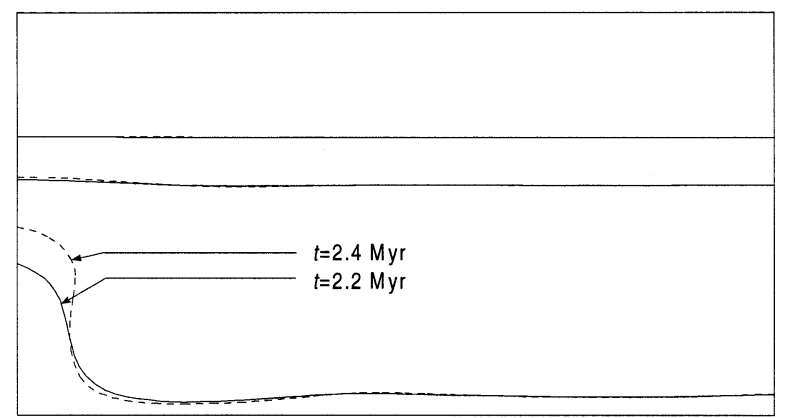

a)

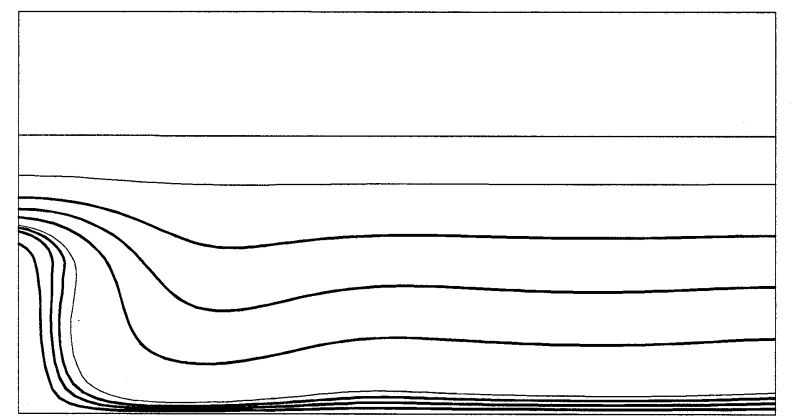

c)

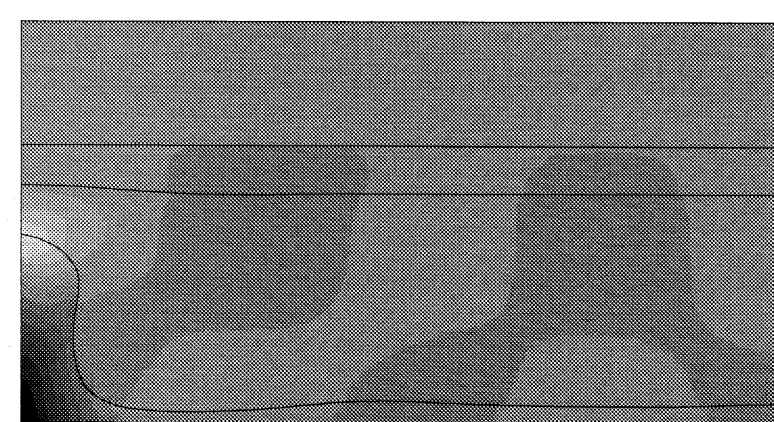

e)

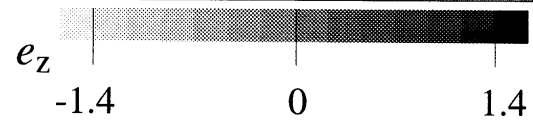

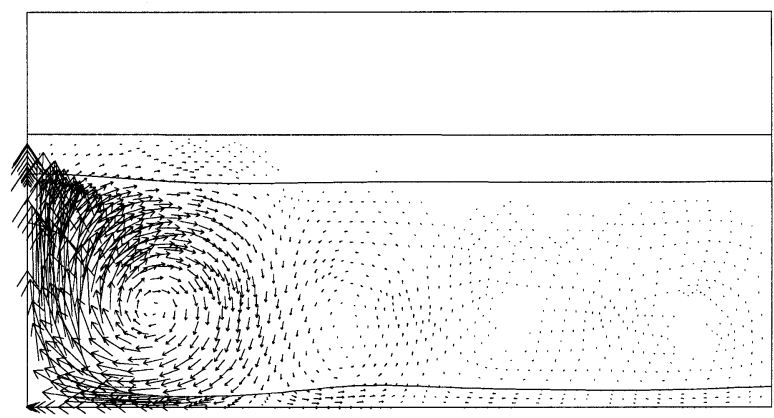

b)

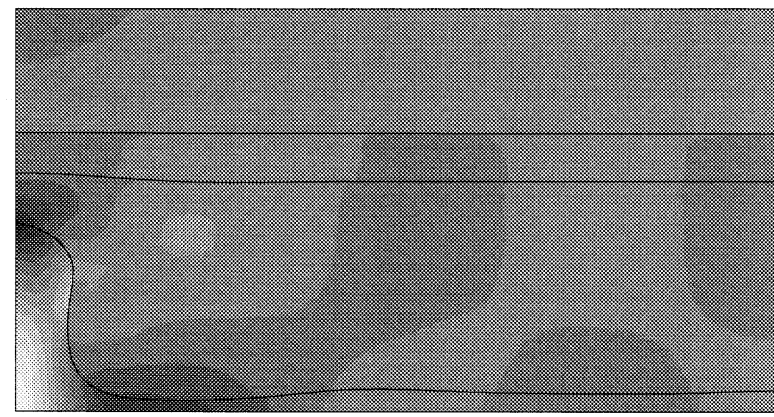

d)
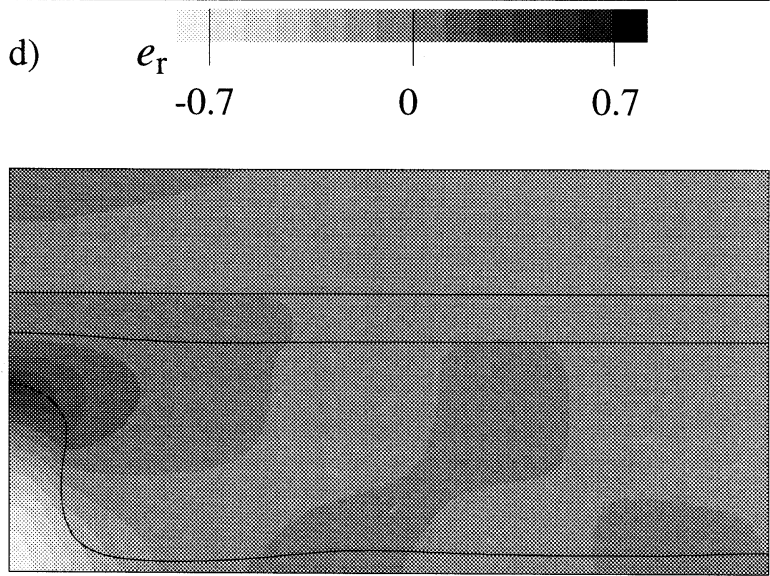

f)

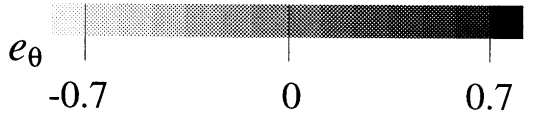

Fig. 8. Basic model amplification phase: (a) deformed geometry at $t=2.2$ m.y. (full line) and $t=2.4$ m.y. (dashed line); (b) velocities at $t=2.4$ m.y.; (c) passive markers (thick lines) at $t=2.4$ m.y.; (d, e, f) radial $e_{\mathrm{r}}$, vertical $e_{\mathrm{z}}$ and circumferential $e_{\theta}$ components of the strain tensor computed for the time range $2.2<t<2.4$ m.y. Negative values indicate compression.

\subsection{Variants of the basic model}

In all the tested models, an instability systematically develops at the interface between the lighter anorthosite and the lower crust, which further evolves in the rise of an anorthosite bulb through the lower crust. Differences in the finite shape of the anorthosite intrusion and in the rate of upward 


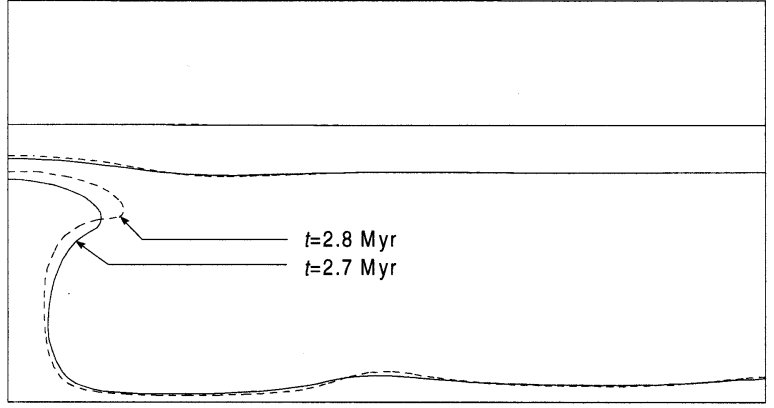

a)

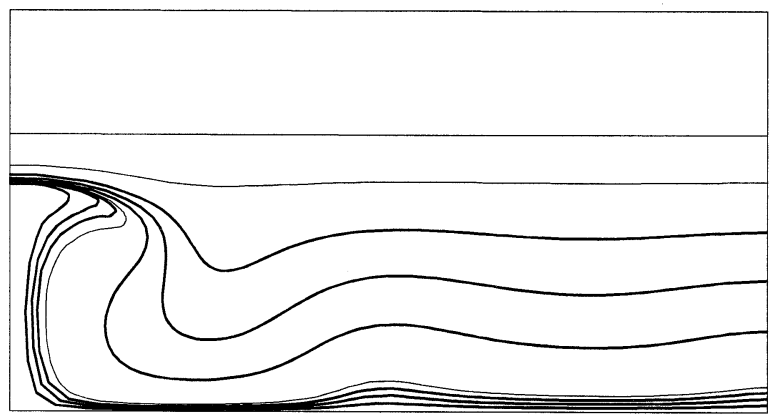

c)

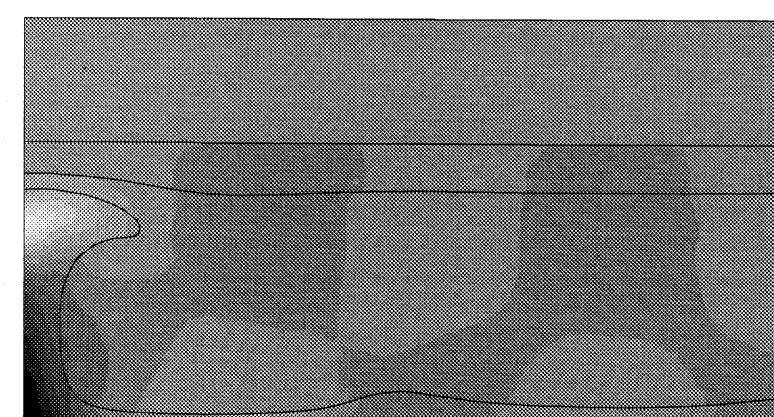

e)

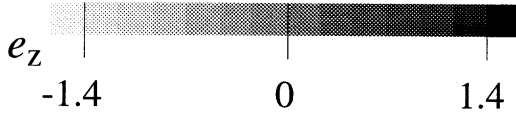

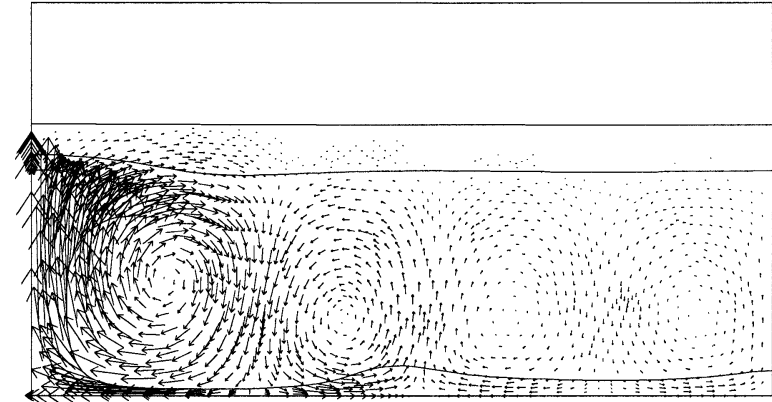

b)

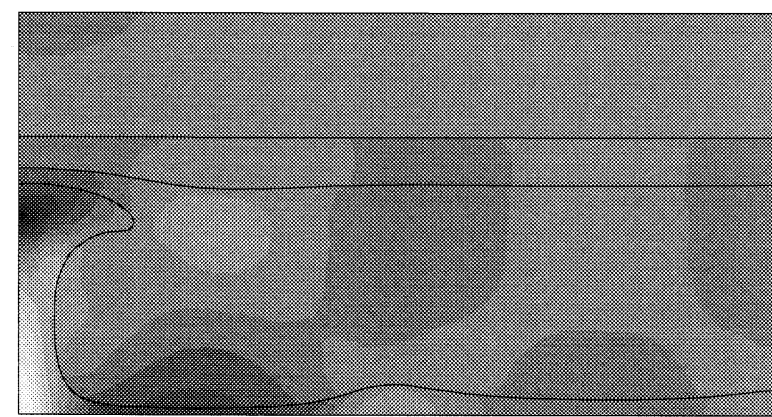

d)
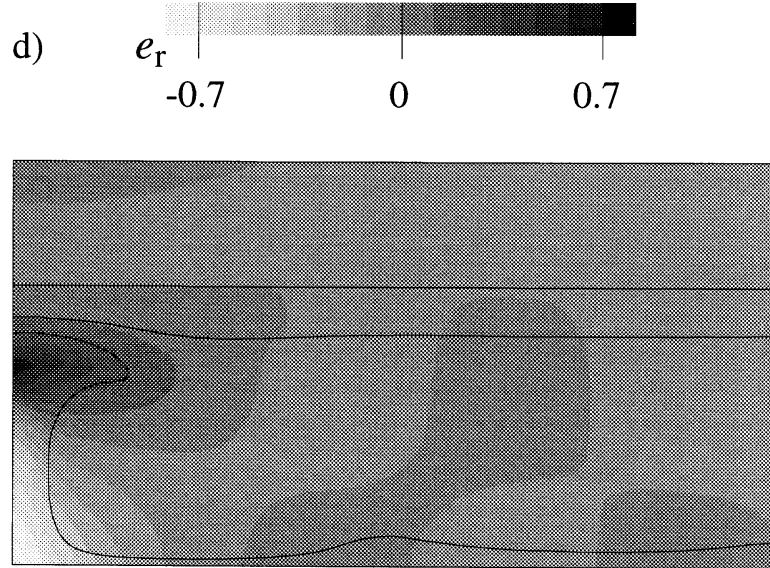

f)

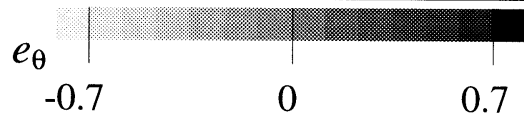

Fig. 9. Basic model damping phase: (a) deformed geometry at $t=2.7$ m.y. (full line) and $t=2.8$ m.y. (dashed line); (b) velocities at $t=2.8$ m.y.; (c) passive markers (thick lines) at $t=2.8$ m.y.; (d, e, f) radial $e_{\mathrm{r}}$, vertical $e_{\mathrm{z}}$ and circumferential $e_{\theta}$ components of the strain tensor computed for the time range $2.7<t<2.8$ m.y. Negative values indicate compression.

flow are observed between the models, and generally agree with results obtained by Woidt (1978). Development of Rayleigh-Taylor instabilities for a wide range of parameter values (viscosity, geometry) is strong evidence of the robustness of modelling results and of their physical meaning. Three of the performed models are briefly presented in the following, highlighting differences with the basic model and in- 
vestigating the influence of anorthosite thickness $h_{\mathrm{a}}$ and viscosity $\eta_{\mathrm{a}}$.

In Model 2, the anorthosite viscosity $\eta_{\mathrm{a}}$ has been divided by 10 . Model 3 is similar to the basic model, except that the anorthosite thickness $h_{\mathrm{a}}$ has been chosen equal to $5 \mathrm{~km}$. Finally, in Model 4, both the anorthosite thickness and viscosity have been changed. The modified parameter values are given in Table 5, while the geometry evolution and the deformed markers are presented in Fig. 10 for the three different models. When the anorthosite viscosity $\eta_{\mathrm{a}}$ is close to the lower crust viscosity $\eta_{\mathrm{n}}$ (basic model and Model 3), the bulb geometry evolves towards a mushroom shape which is wider (radius over $20 \mathrm{~km}$ ), more pronounced with a 5-km-thick anorthosite layer (Model 3, Fig. 10c). On the contrary, if the anorthosite viscosity is much smaller than the lower crust one (Models 2 and 4 for which the ratio $\eta_{\mathrm{n}} / \eta_{\mathrm{a}}=38$ ), the bulb shape evolves towards a geometry with a thicker trunk. Again, the presence of a thicker anorthosite layer allows to increase the massif radius to about $24 \mathrm{~km}$ against $11 \mathrm{~km}$ in Model 3. These results are
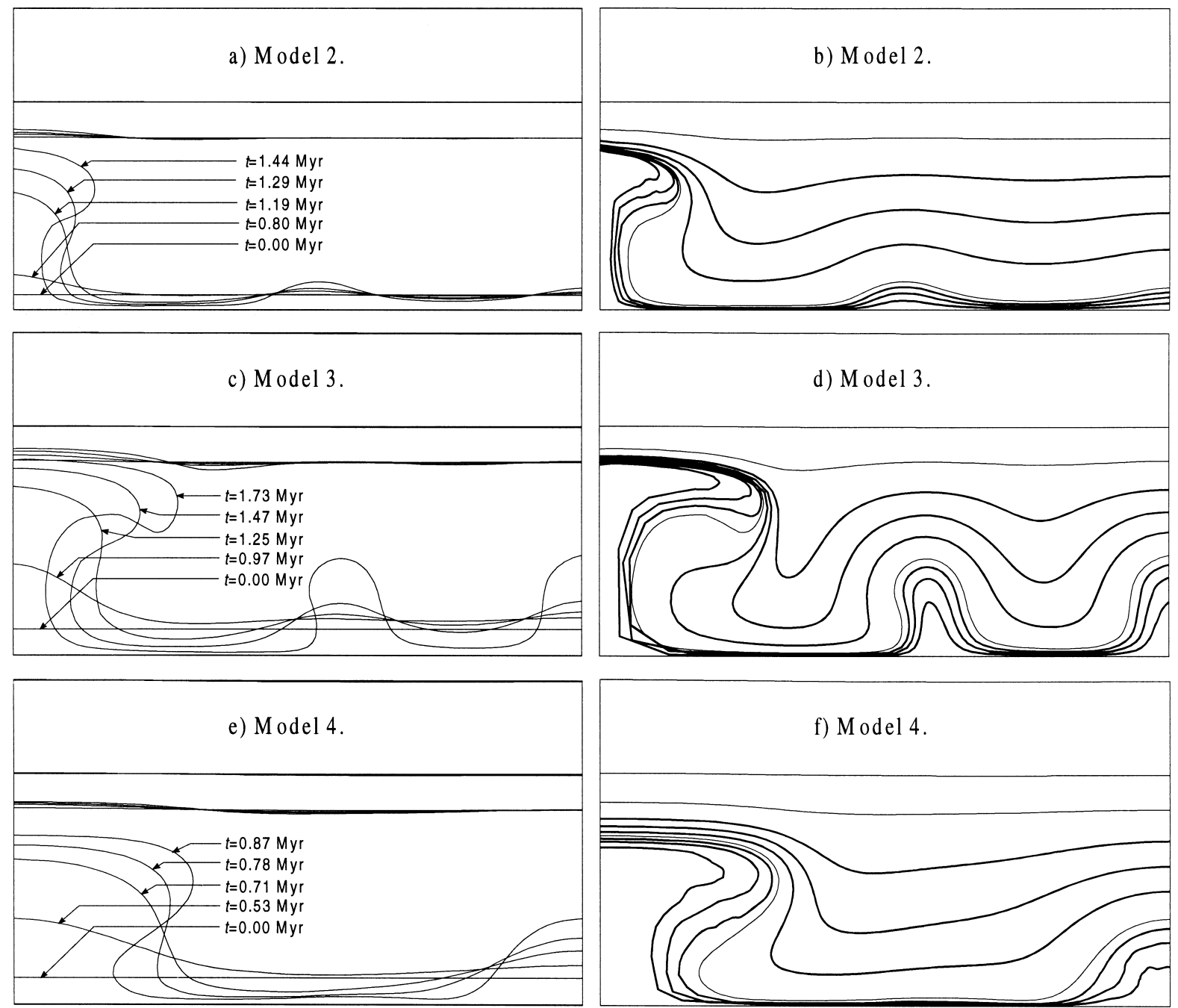

Fig. 10. Influence of anorthosite viscosity and thickness: (a) geometry evolution for Model 2; (b) deformed geometry and markers (thick lines) at $t=1.4$ m.y. for Model 2; (c) geometry evolution for Model 3; (d) deformed geometry and markers (thick lines) at $t=1.7$ m.y. for Model 3; (e) geometry evolution for Model 4; (f) deformed geometry and markers (thick lines) at $t=0.9$ m.y. for Model 4 . 
Table 5

Values of parameters for the variants of the basic model

\begin{tabular}{lll}
\hline Diapir model & $\begin{array}{l}h_{\mathrm{a}} \\
(\mathrm{km})\end{array}$ & $\begin{array}{l}\eta_{\mathrm{a}} \\
(\mathrm{Pa} \mathrm{s})\end{array}$ \\
\hline 1 & 2 & $1.8 \times 10^{19}$ \\
2 & 2 & $1.8 \times 10^{18}$ \\
3 & 5 & $1.8 \times 10^{19}$ \\
4 & 5 & $1.8 \times 10^{18}$ \\
\hline
\end{tabular}

consistent with previous diapir computations (see e.g. Woidt, 1978), which showed that the final geometry is strongly dependent on the source layer thickness. Note also that, when the anorthosite layer is thicker (Models 3 and 4), the rings are well developed and the instability wavelength increases. On the other hand, when the anorthosite is less viscous (Models 2 and 4), the emplacement duration is shorter and the conjugate downward flow within the lower crust is less developed than in the other cases (basic model and Model 3 ). Dividing the viscosity by ten approximately diminishes the emplacement time by a factor two.

In conclusion, for the range of parameter values used in the simulation, the emplacement time strongly depends on the anorthosite viscosity, while the final diameter of the intrusion appears to be mainly controlled by the source layer thickness. For the tested models, the anorthosite body intrudes in a time interval varying between 0.9 and 2.8 m.y., and reaches a final diameter between $24 \mathrm{~km}$ and $48 \mathrm{~km}$. These values are in the range of observations for the EGOG massif. Note also that, when the anorthosite layer is thicker (Models 3 and 4), the rings are well developed and the instability wavelength increases.

\section{Discussion}

The EGOG pristine petrological characters constrain major parameters of its emplacement mechanism in the framework of the classical petrological model of diapirism: the depths of the deep-seated magma chamber and of the final level of intrusion (about $40 \mathrm{~km}$ and $18 \mathrm{~km}$, respectively), the mushy nature, temperature and density of the anorthosite material, the timing of the intrusion (about 2 m.y.), and the anorogenic geodynamic setting. On the other hand, deformed orthopyroxene megacrysts can be used as markers to reconstruct strain ellipsoids and to characterise the strain pattern in the foliated inner margin. The dominant structural features in the margin of EGOG are a sub-horizontal crystal stretching direction parallel to the margin and a decrease of the strain intensity towards the centre of the massif.

FE modelling has been performed with input parameters deriving from petrological constraints in order to test the petrological model in Rogaland. A simple rheological behaviour has been chosen for the anorthosite and the noritic crust, which are characterised by specific viscosity values. A limitation of our computation is thus that the influence of the temperature on the rheology has not been taken into account during the deformation (steady state assumption).

Simulation results show that buoyant rise of anorthositic material actually takes place in quite acceptable timings for a wide range of parameter values. This model can thus be considered as robust and does not require an accurate definition of the state of the material (liquid, solid, crystal mush, plagioclase suspension, etc.) provided a viscosity value is assessed. The displacement of material takes the shape of an anorthosite bulb, which rises through the viscous lower crust until it reaches the limit with the more rigid upper crust. Uprise is usually followed by horizontal expansion which gives a mushroom shape. We suggest to call diapirism the whole process (uprise and expansion), because there is no reason to distinguish two different mechanisms: the phenomenon is continuous and basically the same physical properties control the whole evolution.

FE modelling indicates that anorthosite diapirism is correlated with a downward flow of lower crustal material along the flanks of the structure. In Rogaland, this process could explain the synclinal deformation of the neighbouring BKSK massif, which would adequately be described as a rim syncline.

A good agreement is found between structural data obtained in the margin of the EGOG body and the calculated strain distribution. Observed horizontal lineations in the inner margin correspond to a predominant extension of the circumferential component of the strain tensor occurring during the last stage of deformation. Local occurrence of vertical lineations in the inner margin of EGOG can also be accounted for by the vertical extension computed in 
the lower part of the bulb, but their coexistence next to horizontal lineations is intriguing. More data are needed to decide whether they are relicts transported from the lower part, or whether they result from subsidence of the neighbouring BKSK massif.

Finally, numerical modelling of the EGOG massif demonstrates that the diapirism suggested in the petrological model is an acceptable mechanism for the emplacement of anorthosite through an homogeneous lower crust in an anorogenic setting. It however does not imply that diapirism is the only possible mechanism, nor that it requires such constraining conditions. If buoyancy can explain the phenomenon in a homogeneous crust, a fortiori any weakness zone would favour and channel the uprising through the crust.

\section{Acknowledgements}

The authors have benefited from the constructive comments of four anonymous reviewers and of $\mathrm{R}$. Heilbronner. This work is a contribution to the International Geological Correlation Program, Project 290. Financial support to J.C. Duchesne and B. Hoffer was provided by the Belgian Fund for Basic Joint Research and to H. Havenith by the Fourmarier Foundation.

\section{References}

Ashwal, L., 1993. Anorthosites. Springer, Berlin, 422 pp.

Barnichon, J.D., 1998. Finite Element Modelling in Structural and Petroleum Geology. Doctoral thesis, Université de Liège.

Barnichon, J.D., Charlier, R., 1996. Finite element modelling of the competition between shear bands in the early stages of thrusting: strain localisation analysis and constitutive law influence. In: Buchanan, P.G., Nieuwland, D.A. (Eds.), Modern Developments in Structural Interpretation, Validation and Modelling. Geol. Soc. London Spec. Publ. 99, 235-250.

Brun, J.P., Gapais, D., Le Théoff, B., 1981. The mantled gneiss domes of Kuopo (Finland): interfering diapirs. Tectonophysics 74, 283-304.

Byerlee, J.D., 1978. Friction of rocks. Pure Appl. Geophys. 116, 615-626.

Campbell, I.H., Roeder, P.L., Dixon, J.M., 1978. Plagioclase buoyancy in basaltic liquids as determined with a centrifuge furnace. Contrib. Mineral. Petrol. 67, 369-377.

Carter, N.L., Tsenn, M.C., 1987. Flow properties of continental lithosphere. Tectonophysics 136, 27-63.
Chapman, D.S., 1986. Thermal gradients in the continental crust. In: Dawson, J.B., Carswell, D.A., Hall, J., Wedepohl, K.H. (Eds.), The Nature of the Lower Continental Crust. Geol. Soc. London Spec. Publ. 24, 63-70.

Charlier, R., 1987. Approche unifiée de quelques problèmes non linéaires de mécanique des milieux continus par la méthode des éléments finis. Doctoral thesis, Université de Liège.

Davy, P., Cobbold, P.R., 1991. Experiments on shortening of a 4-layer model of the continental lithosphere. Tectonophysics $188,1-25$.

Duchesne, J.C., 1984. Massif anorthosites: another partisan review. In: Brown, W.S. (Ed.), Feldspars and Feldspathoids. NATO Adv. Stud. Inst., Reidel, Dordrecht, C137, pp. 411433.

Duchesne, J.C., 1987a. The Rogaland intrusive massifs: eastern part. In: Maijer, C., Padget, P. (Eds.), The Geology of Southernmost Norway: An Excursion Guide. Nor. Geol. Unders., Spec. Publ. 1, 63-66.

Duchesne, J.C., 1987b. The Bjerkreim-Sokndal massif. In: Maijer, C., Padget, P. (Eds.), The Geology of Southernmost Norway. Nor. Geol. Unders., Spec. Publ. 1, 56-59.

Duchesne, J.C., Maquil, R., 1987. The Egersund-Ogna massif. In: Maijer, C., Padget, P. (Eds.), The Geology of Southernmost Norway: An Excursion Guide. Nor. Geol. Unders. Spec. Publ. $1,50-56$.

Duchesne, J.C., Maquil, R., Demaiffe, D., 1985. The Rogaland anorthosites: facts and speculations. In: Tobi, A.C., Touret, J.L.R. (Eds.), The Deep Proterozoic Crust in the North Atlantic Province. NATO Adv. Stud. Inst., Reidel, Dordrecht, C158, pp. 449-476.

England, R.W., 1990. The identification of granitic diapirs. J. Geol. Soc. London 147, 931-933.

Falkum, T., 1985. Geotectonic evolution of southern Scandinavia in light of a Late-Proterozoic plate collision. In: Tobi, A.C., Touret, J.L.R. (Eds.), The Deep Proterozoic Crust in the North Atlantic Provinces. NATO Adv. Sci. Inst. Ser., Reidel, Dordrecht, C158, pp. 309-322.

Habraken, A.M., 1989. Contribution à la modélisation du formage des métaux par la méthode des éléments finis. Doctoral Thesis, Université de Liège.

Hall, J., 1986. The physical properties of layered rocks in deep continental crust. In: Dawson, J.B., Carswell, D.A., Hall, J., Wedepohl, K.H. (Eds.), The Nature of the Lower Continental Crust. Geol. Soc. London Spec. Publ. 24, 51-62.

Jackson, M.P.A., Seni, S.J., 1983. Evolution of salt structures, East Texas Diapir Province, 2. Patterns and rates of halokinesis. Am. Assoc. Pet. Geol. Bull. 67 (8), 1245-1274.

Koyi, H., 1991. Mushroom diapirs penetrating overburdens with high effective viscosities. Geology 19, 1229-1232.

Longhi, J., Ashwal, L.D., 1985. Two-stage models for lunar and terrestrial anorthosites: petrogenesis without a magma ocean. Proc. Lunar Planet. Sci. Conf. 15th, Part 2, J. Geophys. Res. 90 (Suppl.), C571-C584.

Longhi, J., Fram, M.S., Vander Auwera, J., Montieth, J.N., 1993. Pressure effects, kinetics, and rheology of anorthositic and related magmas. Am. Mineral. 78, 1016-1030.

Maijer, C., 1987. The metamorphic envelope of the Rogaland in- 
trusive complex. In: Maijer, C., Padget, P. (Eds.), The Geology of Southernmost Norway. Nor. Geol. Unders., Spec. Publ. 1, $68-73$.

Maquil, R., Duchesne, J.C., 1984. Géothermométrie par les pyroxènes et mise en place du massif anorthositique d'EgersundOgna (Rogaland, Norvège méridionale). Ann. Soc. Géol. Belg. 107, 27-49.

Marsh, B.D., 1982. On the mechanics of igneous diapirism, stoping, and zone melting. Am. J. Sci. 282, 808-855.

Martignole, J., 1996. Tectonic setting of anorthositic complexes of the Grenville Province, Canada. In: Demaiffe, D. (Ed.), Petrology and Geochemistry of Magmatic Suites of Rocks in the Continental and Oceanic Crusts. A volume dedicated to Jean Michot, ULB-MRAC, Brussels, pp. 3-18.

Martignole, J., Schrijver, K., 1970. Tectonic significance and evolution of the Morin anorthosite, Grenville Province, Quebec. Bull. Geol. Soc. Finl. 42, 165-209.

Michot, J., Michot, P., 1969. The problem of anorthosites: the South Rogaland igneous complex, southern Norway. In: Isachsen, Y.W. (Ed.), Origin of Anorthosite and Related Rocks. N.Y. State Mus. Sci. Serv. Mem. 18, 399-410.

Milton, N.J., 1980. Determination of the strain ellipsoid from measurement on any three sections. Tectonophysics 64, 1927.

Nettleton, L.L., 1934. Fluids mechanics of salt domes. Am. Assoc. Pet. Geol. Bull. 18 (9), 1175-1204.

Nettleton, L.L., 1943. Recent experimental and geophysical evidence of mechanics of salt-dome formation. Am. Assoc. Pet. Geol. Bull. 27 (1), 51-63.

Paludan, J., Hansen, U.B., Olesen, N.Ø., 1994. Structural evolution of the Precambrian Bjerkreim-Sokndal intrusion, South Norway. Nor. Geol. Tidsskr. 74, 185-198.

Pasteels, P., Demaiffe, D., Michot, J., 1979. U-Pb and RbSr geochronology of the eastern part of the south Rogaland igneous complex, southern Norway. Lithos 12, 199-208.

Paterson, S.R., Fowler, T.K., 1993. Re-examining pluton emplacement processes. J. Struct. Geol. 15, 191-206.

Paterson, S.R., Vernon, R.H., 1996. Bursting the bubble of ballooning plutons: a return to nested diapirs emplaced by multiple processes. Geol. Soc. Am. Bull. 107, 1356-1380.

Paterson, S.R., Vernon, R.H., Fowler, T.K., 1991. Aureole tectonics. In: Kerrick, D.M. (Ed.), Contact Metamorphism. Mineralogical Society of America, 26, pp. 673-722.

Pitcher, W.S., Berger, A.R., 1972. The Geology of Donegal. A Study of Granite Emplacement and Unroofing. Wiley, New York, $435 \mathrm{pp}$.

Poliakov, A.N.B., Cundall, P.A., Podladchikov, Y.Y., Lyakhovsky, V.A., 1993. An explicit inertial method for the simulation of viscoelastic flow: an evaluation of elastic effects on diapiric flow in two and three-layers models. In: Stone, D.B., Runcorn, S.K. (Eds.), Flow and Creep in the Solar System: Observations, Modelling and Theory. Kluwer, Amsterdam, pp. 175195.

Poliakov, A.N.B., Podladchikov, Y.Y., Dawson, E.CH., Talbot, C.J., 1996. Salt diapirism with simultaneous brittle faulting and viscous. In: Alsop, G.I., Blundell, D.J., Davison, I. (Eds.),
Salt Tectonics. Geol. Soc. London Spec. Publ. 100, 291-302.

Ramberg, H., 1967. Gravity, Deformation and the Earth's Crust as Studied by Centrifuged Models. Academic Press, New York, $214 \mathrm{pp}$.

Ramberg, H., 1981. Gravity, Deformation and the Earth's Crust. Academic Press, London, 405 pp.

Ramsay, J.G., Huber, M.I., 1983. The Techniques of Modern Structural Geology, Vol. 1. Strain Analysis. Academic press, London, 307 pp.

Ratschbacher, L., Spemer, B., Meschede, M., Frisch, W., 1994. Computer Teckniken und Anwendungen: Eine Programmbiblothek zur quantitativen Structuranalyse. Institut und $\mathrm{Mu}-$ seum für Geologie und Paläontologie, Tübingen.

Rönnlund, P., 1989. Viscosity estimates from natural RayleighTaylor instabilities. Terra Nova 1, 344-348.

Schärer, U., Wilmart, E., Duchesne, J.C., 1996. The short duration and anorogenic character of anorthosite magmatism: $\mathrm{U}-\mathrm{Pb}$ dating of the Rogaland complex, Norway. Earth Planet. Sci. Lett. 139, 335-350.

Schmeling, H., 1987. On the relation between initials conditions and late stages of Rayleigh-Taylor instabilities. Tectonophysics $133,65-80$.

Scoates, J.S., Chamberlain, K.R., 1997. Orogenic to post-orogenic origin for the $1.76 \mathrm{Ga}$ Horse Creek anorthosite complex, Wyoming, USA. J. Geol. 105, 331-343.

Sibson, R.H., 1974. Frictional constraint on thrust, wrench and normal faults. Nature 249, 542-544.

Talbot, C.J., Rönnlund, P., Schmeling, H., Jackson, M.P.A., Koyi, H., 1991. Diapiric spoke patterns. Tectonophysics 188, $187-$ 201.

Vander Auwera, J., Longhi, J., 1994. Experimental study of a jotunite (hypersthene monzodiorite): constraints on the parent magma composition and crystallization conditions $\left(P, T, f_{\mathrm{O}_{2}}\right)$ of the Bjerkreim-Sokndal layered intrusion. Contrib. Mineral. Petrol. 118, 60-78.

Van Eekelen, H.A.M., 1980. Isotropic yield surfaces in three dimensions for use in soil mechanics. Int. J. Num. Anal. Meth. Geomech. 4, 98-101.

Vernon, R.H., Paterson, S.R., 1993. The Ardara pluton, Ireland: deflating an expanded intrusion. Lithos 31, 17-32.

Vigneresse, J.L., 1995. Crustal regime of deformation and ascent of granitic magma. Tectonophysics 249, 187-202.

Wiebe, R.A., 1992. Proterozoic anorthosite complexes. In: Condie, K.C. (Ed.), Proterozoic Crustal Evolution. Elsevier, Amsterdam, pp. 215-262.

Wilson, J.R., Robins, B., Nielsen, F., Duchesne, J.C., Vander Auwera, J., 1996. The Bjerkreim-Sokndal layered intrusion, Southwest Norway. In: Cawthorn, R.G. (Ed.), Layering in Igneous Complexes. Elsevier, Amsterdam, pp. 231-256.

Woidt, W.D., 1978. Finite element calculations applied to saltdome analysis. Tectonophysics 50, 369-386.

Zaleski, S., Julien, P., 1992. Numerical simulation of RayleighTaylor instability for single and multiple salt diapirs. Tectonophysics 206, 55-69.

Zienkiewicz, O.C., Taylor, R.L., 1989. The Finite Element Method. McGraw-Hill, London, 4th ed., 648 pp. 